\title{
Methane and nitrous oxide fluxes across an elevation gradient in the tropical Peruvian Andes
}

\author{
Y. A. Teh ${ }^{1, *}$, T. Diem ${ }^{1}$, S. Jones ${ }^{2}$, L. P. Huaraca Quispe ${ }^{3}$, E. Baggs ${ }^{4}$, N. Morley ${ }^{4}$, M. Richards ${ }^{4}$, P. Smith ${ }^{4}$, and P. Meir ${ }^{2,5}$ \\ ${ }^{1}$ Department of Earth and Environmental Sciences, University of St Andrews, Scotland, UK \\ ${ }^{2}$ School of Geosciences, University of Edinburgh, Scotland, UK \\ ${ }^{3}$ Universidad Nacional de San Antonio Abad del Cusco, Peru \\ ${ }^{4}$ Institute of Biological and Environmental Sciences, University of Aberdeen, Scotland, UK \\ ${ }^{5}$ Research School of Biology, Australian National University, Canberra, Australia \\ *now at: Institute of Biological and Environmental Sciences, University of Aberdeen, Cruickshank Building, St Machar \\ Drive, Aberdeen, AB24 3UU, Scotland, UK
}

Correspondence to: Y. A. Teh (yateh@abdn.ac.uk)

Received: 30 September 2013 - Published in Biogeosciences Discuss.: 5 November 2013

Revised: 17 February 2014 - Accepted: 8 March 2014 - Published: 25 April 2014

\begin{abstract}
Remote sensing and inverse modelling studies indicate that the tropics emit more $\mathrm{CH}_{4}$ and $\mathrm{N}_{2} \mathrm{O}$ than predicted by bottom-up emissions inventories, suggesting that terrestrial sources are stronger or more numerous than previously thought. Tropical uplands are a potentially large and important source of $\mathrm{CH}_{4}$ and $\mathrm{N}_{2} \mathrm{O}$ often overlooked by past empirical and modelling studies. To address this knowledge gap, we investigated spatial, temporal and environmental trends in soil $\mathrm{CH}_{4}$ and $\mathrm{N}_{2} \mathrm{O}$ fluxes across a long elevation gradient (600-3700 ma.s.1.) in the Kosñipata Valley, in the southern Peruvian Andes, that experiences seasonal fluctuations in rainfall. The aim of this work was to produce preliminary estimates of soil $\mathrm{CH}_{4}$ and $\mathrm{N}_{2} \mathrm{O}$ fluxes from representative habitats within this region, and to identify the proximate controls on soil $\mathrm{CH}_{4}$ and $\mathrm{N}_{2} \mathrm{O}$ dynamics. Area-weighted flux calculations indicated that ecosystems across this altitudinal gradient were both atmospheric sources and sinks of $\mathrm{CH}_{4}$ on an annual basis. Montane grasslands (3200-3700 m a.s.l.) were strong atmospheric sources, emitting $56.94 \pm 7.81 \mathrm{~kg} \mathrm{CH}_{4}-\mathrm{C} \mathrm{ha}^{-1} \mathrm{yr}^{-1}$. Upper montane forest (2200-3200 m a.s.1.) and lower montane forest (1200-2200 m a.s.1.) were net atmospheric sinks $\left(-2.99 \pm 0.29\right.$ and $-2.34 \pm 0.29 \mathrm{~kg} \mathrm{CH}_{4}-\mathrm{Cha}^{-1} \mathrm{yr}^{-1}$, respectively); while premontane forests (600-1200 ma.s.1.) fluctuated between source or sink depending on the season (wet season: $1.86 \pm 1.50 \mathrm{~kg} \mathrm{CH}_{4}-\mathrm{Cha}^{-1} \mathrm{yr}^{-1}$; dry season: $-1.17 \pm 0.40 \mathrm{~kg} \mathrm{CH}_{4}-\mathrm{C} \mathrm{ha}^{-1} \mathrm{yr}^{-1}$ ). Analysis of spatial, tem-
\end{abstract}

poral and environmental trends in soil $\mathrm{CH}_{4}$ flux across the study site suggest that soil redox was a dominant control on net soil $\mathrm{CH}_{4}$ flux. Soil $\mathrm{CH}_{4}$ emissions were greatest from habitats, landforms and during times of year when soils were suboxic, and soil $\mathrm{CH}_{4}$ efflux was inversely correlated with soil $\mathrm{O}_{2}$ concentration (Spearman's $\rho=-0.45, P<0.0001$ ) and positively correlated with water-filled pore space (Spearman's $\rho=0.63, P<0.0001)$. Ecosystems across the region were net atmospheric $\mathrm{N}_{2} \mathrm{O}$ sources. Soil $\mathrm{N}_{2} \mathrm{O}$ fluxes declined with increasing elevation; area-weighted flux calculations indicated that $\mathrm{N}_{2} \mathrm{O}$ emissions from premontane forest, lower montane forest, upper montane forest and montane grasslands averaged $2.23 \pm 1.31,1.68 \pm 0.44,0.44 \pm 0.47$ and $0.15 \pm 1.10 \mathrm{~kg} \mathrm{~N}_{2} \mathrm{O}-\mathrm{N} \mathrm{ha}^{-1} \mathrm{yr}^{-1}$, respectively. Soil $\mathrm{N}_{2} \mathrm{O}$ fluxes from premontane and lower montane forests exceeded prior model predictions for the region. Comprehensive investigation of field and laboratory data collected in this study suggest that soil $\mathrm{N}_{2} \mathrm{O}$ fluxes from this region were primarily driven by denitrification; that nitrate $\left(\mathrm{NO}_{3}^{-}\right)$availability was the principal constraint on soil $\mathrm{N}_{2} \mathrm{O}$ fluxes; and that soil moisture and water-filled porosity played a secondary role in modulating $\mathrm{N}_{2} \mathrm{O}$ emissions. Any current and future changes in $\mathrm{N}$ management or anthropogenic $\mathrm{N}$ deposition may cause shifts in net soil $\mathrm{N}_{2} \mathrm{O}$ fluxes from these tropical montane ecosystems, further enhancing this emission source. 


\section{Introduction}

Recent remote sensing and inverse modelling studies indicate that the tropics emit more methane $\left(\mathrm{CH}_{4}\right)$ and nitrous oxide $\left(\mathrm{N}_{2} \mathrm{O}\right)$ than estimated from prior bottom-up emissions inventories, suggesting that tropical sources are stronger or more numerous than previously thought (Frankenberg et al., 2008; Frankenberg et al., 2005; Bergamaschi et al., 2009; Fletcher et al., 2004a, b; Hirsch et al., 2006; Huang et al., 2008; Kort et al., 2011). Recent speculation over discrepancies in the global tropical $\mathrm{CH}_{4}$ budget have focussed on the potential role of seasonally flooded wetlands (Melack et al., 2004; Bergamaschi et al., 2009) or vegetation in accounting for budgetary gaps; the latter acting as abiotic producers (Bergamaschi et al., 2007; Keppler et al., 2006), sites of methanogenic activity (Martinson et al., 2010; Covey et al., 2012) or conduits for atmospheric egress from anoxic soils (Gauci et al., 2010; Terazawa et al., 2007; Pangala et al., 2013). Parallel debates over tropical $\mathrm{N}_{2} \mathrm{O}$ budgets have invoked rising agricultural emissions or atmospheric transport processes as possible causes for discrepancies between topdown and bottom-up budgets (Nevison et al., 2007, 2011; Kort et al., 2011).

One potentially important source of $\mathrm{CH}_{4}$ and $\mathrm{N}_{2} \mathrm{O}$ overlooked both by bottom-up inventories and top-down studies are fluxes from tropical upland soils (Spahni et al., 2011), because attention has historically focussed on seasonally inundated wetlands (e.g. várzea in Brazil) (Fung et al., 1991; Bergamaschi et al., 2009; Melack et al., 2004; Werner et al., 2007), lowland forests, savannas, or pastures (Hall and Matson, 1999; Silver et al., 1999; Teh et al., 2005; Werner et al., 2007; Keller et al., 1986, 1993; Verchot et al., 2000; Keller and Reiners, 1994). However, upland ecosystems account for a substantial fraction of land cover in the tropics; in South America alone, upland ecosystems (> $500 \mathrm{~m}$ a.s.l.) represent more than $8 \%$ of total continental land cover (Eva et al., 2004), while in mountainous countries, such as Peru or other Andean states, upland ecosystems may account for upwards of $80 \%$ of total land cover (Feeley and Silman, 2010). Measurements from tropical uplands in Australia (Breuer et al., 2000), Ecuador (Wolf et al., 2012, 2011), Hawaii (Hall and Matson, 1999; von Fischer and Hedin, 2002, 2007), Puerto Rico (Silver et al., 1999; Teh et al., 2005) and Sulawesi (Veldkamp et al., 2008; Purbopuspito et al., 2006) indicate that $\mathrm{CH}_{4}$ and $\mathrm{N}_{2} \mathrm{O}$ fluxes from these environments are comparable or greater than those from tropical lowlands, and may therefore be quantitatively important in regional and global atmospheric budgets, particularly if these ecosystems function as regional "hotspots" of gas production or consumption (Teh et al., 2011; Waddington and Roulet, 1996). Soil $\mathrm{CH}_{4}$ fluxes in tropical uplands are particularly intriguing because they show no clear regional patterns or trends. While some ecosystems function as net atmospheric sources, others operate as net atmospheric sinks (Silver et al., 1999; Teh et al., 2005; Veldkamp et al., 2008; von Fischer and Hedin,
2002; Wolf et al., 2011, 2012). Soil $\mathrm{N}_{2} \mathrm{O}$ fluxes are more predictable, but are still poorly constrained (Werner et al., 2007); upland ecosystems, like their lowland counterparts, act as net $\mathrm{N}_{2} \mathrm{O}$ sources, with emission rates modulated by factors such as soil moisture, water-filled pore space, soil oxygen content, $\mathrm{pH}$, redox potential, $\mathrm{C}$ availability, inorganic $\mathrm{N}$ availability $\left(\mathrm{NH}_{4}^{+}, \mathrm{NO}_{3}^{-}\right)$, or competition for $\mathrm{NO}_{3}^{-}$among different soil sinks (Hall and Matson, 1999; Silver et al., 1999, 2001; Veldkamp et al., 2008; Wolf et al., 2011; Firestone and Davidson, 1989).

In the Neotropics, data on upland $\mathrm{CH}_{4}$ and $\mathrm{N}_{2} \mathrm{O}$ fluxes are particularly scarce, with field observations only from Puerto Rico (Silver et al., 1999; Teh et al., 2005) and Ecuador (Wolf et al., 2011, 2012). Because of the limited spatial coverage and aseasonality of these two regions, it is difficult to draw wider conclusions about the source or sink strength of Neotropical uplands for $\mathrm{CH}_{4}$ and $\mathrm{N}_{2} \mathrm{O}$, particularly for areas that experience marked seasonality in rainfall or temperature. To address these knowledge gaps, we performed a preliminary study of soil $\mathrm{CH}_{4}$ and $\mathrm{N}_{2} \mathrm{O}$ cycling across a long elevation gradient (600-3700 m a.s.l.) in the Peruvian Andes that experiences seasonal variations in rainfall, and include a wide range of habitats stretching from premontane forests to wet montane grasslands. Our principal objectives were to:

1. quantify spatial (habitat, landform) and temporal (seasonal, month-to-month) trends in soil $\mathrm{CH}_{4}$ and $\mathrm{N}_{2} \mathrm{O}$ fluxes;

2. evaluate the role of environmental variables in modulating soil $\mathrm{CH}_{4}$ and $\mathrm{N}_{2} \mathrm{O}$ dynamics.

Findings from this research will provide the basis for future, more detailed and integrative studies of soil trace gas dynamics in seasonal montane tropical ecosystems; and will also enable us to identify the proximate controls on soil $\mathrm{CH}_{4}$ and $\mathrm{N}_{2} \mathrm{O}$ fluxes in these diverse environments.

\section{Methods and materials}

\subsection{Study site}

Measurements were conducted on the eastern slope of the Andes in the Kosñipata Valley, Manu National Park, Peru (Malhi et al., 2010) (Fig. 1). This $3.02 \times 10^{6}$ ha $\left(30200 \mathrm{~km}^{2}\right.$ ) region has been the subject of intensive ecological, biogeochemical and climatological studies since 2003 by the Andes Biodiversity and Ecosystem Research Group (or, ABERG; http://www.andesconservation.org), and contains a series of long-term permanent plots across a 200-3700 m a.s.l. elevation gradient stretching from the western Amazon to the Andes (Malhi et al., 2010; Feeley and Silman, 2010). This part of the Andes experiences pronounced seasonality in rainfall but not in air temperature; the dry season extends from May to September and the wet season from October to April (Girardin et al., 2010; Zimmermann et al., 
Table 1. Site characteristics.

\begin{tabular}{|c|c|c|c|c|c|c|c|c|c|c|c|c|c|c|}
\hline $\begin{array}{l}\text { Elevation } \\
\text { Band } \\
\text { (m a.s.l.) }\end{array}$ & Habitat & $\begin{array}{l}\text { Areal Coverage } \\
\text { in the } \\
\text { Kosñipata Valley } \\
\left(\mathrm{km}^{2}\right)\end{array}$ & Site Name & Latitude & $\begin{array}{l}\text { Longitude } \\
\text { (W) }\end{array}$ & $\begin{array}{l}\text { Mean Annual } \\
\text { Temperature } \\
\left({ }^{\circ} \mathrm{C}\right)\end{array}$ & $\begin{array}{l}\text { Mean Annual } \\
\text { Precipitation } \\
(\mathrm{mm})\end{array}$ & $\begin{array}{l}\text { Bulk density } \\
\text { A horizon } \\
\left(\mathrm{g} \mathrm{cm}^{-3}\right)\end{array}$ & $\mathrm{pH}$ & $\begin{array}{l}\text { Soil C/N } \\
\text { A horizon }\end{array}$ & $\begin{array}{l}\text { Carbon } \\
\text { A horizon } \\
(\%)\end{array}$ & $\begin{array}{l}\text { Landforms } \\
\text { (mesotopes) }\end{array}$ & Plots & $\begin{array}{l}\text { Flux } \\
\text { Chambers }\end{array}$ \\
\hline $600-1200$ & Premontane forest & 7334 & $\begin{array}{l}\text { Hacienda } \\
\text { Villa Carmen }\end{array}$ & $12^{\circ} 53^{\prime} 43^{\prime \prime}$ & $71^{\circ} 24^{\prime} 04^{\prime \prime}$ & 23.4 & 5318 & 0.30 & 3.4 & 15 & 3 & ridge, slope, flat & 3 & 15 \\
\hline $1200-2200$ & Lower montane forest & 8923 & San Pedro & $13^{\circ} 2^{\prime} 56^{\prime \prime}$ & $71^{\circ} 32^{\prime} 13^{\prime \prime}$ & 18.8 & 2631 & 0.31 & 3.4 & 15 & 11 & ridge, slope, flat & 3 & 15 \\
\hline $2200-3200$ & Upper montane forest & 8066 & Wayqecha & $13^{\circ} 11^{\prime} 24^{\prime \prime}$ & $71^{\circ} 35^{\prime} 13^{\prime \prime}$ & 12.5 & 1706 & 0.41 & 3.9 & 25 & 47 & slope, flat & 3 & 15 \\
\hline $3200-3700$ & Montane grasslands & 5859 & Tres Cruces & $13^{\circ} 07^{\prime} 19^{\prime \prime}$ & $71^{\circ} 36^{\prime} 54^{\prime \prime}$ & 11.8 & 2200 & 0.36 & 4.1 & 14 & 10 & ridge, slope, flat, basin & 4 & 20 \\
\hline
\end{tabular}

2010b). Thirteen sampling plots (approximately $20 \times 20 \mathrm{~m}$ each) were established at four different habitats across a gradient spanning 600-3700 ma.s.l., including premontane forest (600-1200 ma.s.l.; $n=3$ plots), lower montane forest (1200-2200 ma.s.l.; $n=3$ plots), upper montane forest (2200-3200 ma.s.1.; $n=3$ plots), and montane grasslands (3200-3700 m a.s.l.; $n=4$ plots; colloquially referred to as "puna") (Fig. 1). In premontane forest, new sampling plots were established in Hacienda Villa Carmen, a 3065 ha biological reserve operated by the Amazon Conservation Association (ACA), containing a mixture of old-growth forest, secondary forest and agricultural plots. Sampling for soil gas fluxes was concentrated in the old-growth portions of the reserve. For lower montane and upper montane forests, sampling plots were established adjacent to or within existing 1 ha permanent sampling plots established by ABERG. New sampling plots were also established in montane grasslands to capture a representative range of environmental conditions, microforms (1-5 m scale landforms) and mesotopes (100 m-1 km scale landforms) (Belyea and Baird, 2006), as past ABERG studies of the biogeochemistry of montane grasslands were more limited in both intensity and spatial extent (Gibbon et al., 2010; Zimmermann et al., 2010b). Mesotopic features include ridges, slopes, flats and basins. The latter two landforms include wet, grassy lawns with no discernible grade; and peat-filled depressions found in valley bottoms, respectively. Some (although not all) of these basins abut pool or lake complexes. Because of the logistic challenges of sampling over open water, we did not collect data from the pools or lakes, nor from the shoreline. Summary site descriptions are provided in Table 1 with data on site characteristics collated from prior studies (Feeley and Silman, 2010; Girardin et al., 2010; Zimmermann et al., 2009, 2010b).

\subsection{Soil-atmosphere exchange}

Field sampling was performed over a 13-month period from December 2010 to December 2011 for all habitats except premontane forest. Because of circumstances outside our control, only 6-months of data were collected for premontane forest, with sampling commencing in July 2011. Soilatmosphere fluxes were collected monthly, except where flooding or landslides prevented safe access by fieldworkers to the study sites. Gas exchange rates were determined with five replicate gas flux chambers deployed in each of the 13

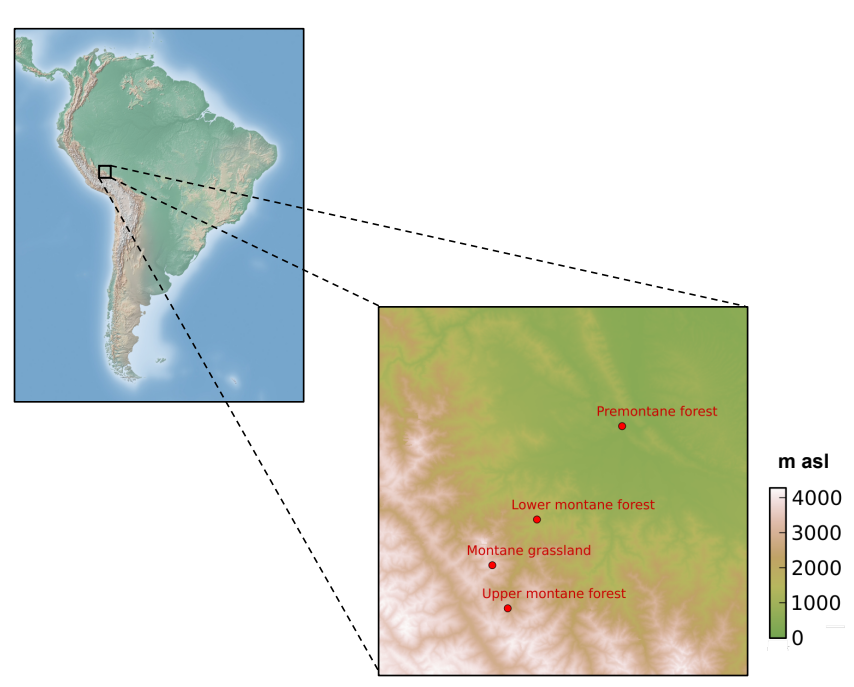

Fig. 1. Map of study sites across the Kosñipata Valley, Manu National Park, Peru.

plots ( $n=65$ flux observations per month). Sampling was spatially stratified to account for mesotope $(100 \mathrm{~m}-1 \mathrm{~km})$ scale variability in redox and hydrologic conditions (Belyea and Baird, 2006); key environmental factors that often regulate soil-atmosphere trace gas fluxes (Silver et al., 1999; Teh et al., 2011). All representative landforms were sampled in each habitat, including ridges, slopes, flats and basins (Table 1). This spatial stratification of sampling was justified by a prior pilot study conducted across the entire ABERG elevation gradient (i.e. 220-3700 m a.s.l.), which found significant within- and among-plot variability in fluxes, suggesting the need for spatially explicit sampling (Saiz and Teh, 2009, unpublished data; $n=75$ static chamber measurements; $>10$ flux measurements per elevation).

Daily sampling in montane grasslands were performed over 12 days (from 11-22 November 2011) in order to determine if soil trace gas fluxes varied among mesotope-scale landforms (ridge, slope, flat, basin) in response to shortterm (daily) fluctuations in rainfall, water table depth and soil moisture content. Sampling followed a stratified design that encompassed a 2.5 ha area including ridge, slope, flat and basin landforms. Twenty-four sampling stations were set up across this topographic gradient $>1$ month prior to sampling, consisting of six $75 \mathrm{~m}$ long transects, each running perpendicular to the slope and containing four sampling stations 
each. Each sampling station was instrumented with a chamber base, a soil gas equilibration chamber buried at a depth of $10 \mathrm{~cm}$ (Teh et al., 2005), and a piezometer inserted to bedrock or saprolite depth $(\leq 50 \mathrm{~cm})$. Measurements of air temperature, flux chamber temperature, soil temperature (5 and $10 \mathrm{~cm}$ depth), atmospheric pressure, soil moisture $(0$ $20 \mathrm{~cm})$, soil oxygen $\left(\mathrm{O}_{2}\right)$ concentration and water table depth were collected concurrent with flux chamber measurements on a daily basis.

Soil-atmosphere fluxes of $\mathrm{CH}_{4}, \mathrm{~N}_{2} \mathrm{O}$ and $\mathrm{CO}_{2}$ were determined using a static flux chamber approach (Teh et al., 2011, Livingston and Hutchinson, 1995), although only $\mathrm{CH}_{4}$ and $\mathrm{N}_{2} \mathrm{O}$ fluxes are reported here. Static flux chamber measurements were made by enclosing a $0.03 \mathrm{~m}^{2}$ area with cylindrical, opaque (i.e. dark), two-component (i.e. base and lid) vented chambers. Chamber bases were permanently installed to a depth of approximately $5 \mathrm{~cm}$ and inserted $>1$ month prior to the commencement of sampling, in order to minimize potential artefacts from root mortality following base emplacement (Varner et al., 2003). Chamber lids were fitted with small computer case fans to promote even mixing in the chamber headspace (Pumpanen et al., 2004). Headspace samples were collected from each flux chamber over a $30 \mathrm{~min}$ enclosure period, with samples collected at four discrete intervals using a gastight syringe. Gas samples were stored in evacuated Exetainers ${ }^{\circledR}$ (Labco Ltd., Lampeter, UK), shipped to the UK by courier, and subsequently analysed for $\mathrm{CH}_{4}$, $\mathrm{N}_{2} \mathrm{O}$ and $\mathrm{CO}_{2}$ concentrations with a Thermo TRACE GC Ultra (Thermo Fisher Scientific Inc., Waltham, Massachusetts, USA) at the University of St Andrews. Chromatographic separation was achieved using a Porapak-Q column, and analyte concentrations quantified using a flame ionization detector (FID) for $\mathrm{CH}_{4}$, electron capture detector (ECD) for $\mathrm{N}_{2} \mathrm{O}$, and methanizer-FID for $\mathrm{CO}_{2}$. Instrumental precision was determined by repeated analysis of standards and was better than $5 \%$ for all detectors. Fluxes were determined by using the $\mathrm{R}$ (R Core Team, 2012) HMR package to plot best-fit lines to the data for headspace concentration against time for individual flux chambers (Pedersen et al., 2010). Gas mixing ratios (ppm) were converted to areal fluxes by using the Ideal Gas Law to solve for the quantity of gas in the headspace (on a mole or mass basis), normalized by the surface area of each static flux chamber (Livingston and Hutchinson, 1995).

\subsection{Environmental variables}

To investigate the effects of environmental variables on trace gas dynamics, we determined soil moisture, soil oxygen content in the $0-10 \mathrm{~cm}$ depth, soil temperature, chamber temperature and air temperature at the time of flux sampling. In flooded environments (e.g. basins in montane grasslands), water table depth was also measured using piezometers installed to a depth of $\leq 50 \mathrm{~cm}$ in the soil. Soil moisture was determined using portable moisture probes (ML2x ThetaProbe, Delta-T Device Ltd., Cambridge, UK) inserted into the sub- strate immediately adjacent to each flux chamber $(<5 \mathrm{~cm}$ from each chamber base; depth of $0-10 \mathrm{~cm}$ ). Soil moisture content was measured both as volumetric water content (VWC) and water-filled pore space (WFPS), the latter calculated from VWC and bulk density data (Breuer et al., 2000). For sake of brevity, only WFPS numbers are reported in the body of the text, while both VWC and WFPS data are reported in tables. Soil $\mathrm{O}_{2}$ concentration was determined by analysing soil gas with a portable $\mathrm{O}_{2}$ meter (Apogee Instruments Ltd., Logan, Utah, USA), collected from soil gas equilibration chambers (Teh et al., 2005). Soil gas equilibration chambers were constructed from gas-permeable silicone tubing (Clark et al., 2001, Kammann et al., 2001), and permanently installed to a depth of $0-10 \mathrm{~cm}$, adjacent to each static flux chamber. Soil $\mathrm{O}_{2}$ was measured by withdrawing $40 \mathrm{~mL}$ of soil gas from each soil gas equilibration chamber using a stopcock and gastight syringe. The gas sample was then passed through the flow-through head of the $\mathrm{O}_{2}$ meter into a second syringe. After the $\mathrm{O}_{2}$ measurement was made, the soil gas was re-injected into the soil gas equilibration chamber using the second syringe. Dead volumes were flushed prior to sampling to reduce the likelihood of contamination by atmospheric air or by residual stagnant gas within the sampling system. Soil temperature $(0-10 \mathrm{~cm}$ depth), chamber temperature and air temperature was determined using type $\mathrm{K}$ thermocouples (Omega Engineering Ltd., Manchester, UK). Data on aboveground litterfall, meteorological variables (i.e. photosynthetically active radiation, air temperature, relative humidity, rainfall, wind speed, wind direction), continuous plot-level soil moisture and soil temperature measurements $(10 \mathrm{~cm}$ and $30 \mathrm{~cm}$ depths) were also collected, but are not reported in this publication.

Available inorganic $\mathrm{N}$ (i.e. ammonium, $\mathrm{NH}_{4}^{+}$; nitrate, $\mathrm{NO}_{3}^{-}$; nitrite, $\mathrm{NO}_{2}^{-}$) concentrations were quantified in all plots using a resin bag approach (Templer et al., 2005). From August 2011 onwards, ion exchange resin bags $(n=15$ resin bags per elevation) were deployed at the bottom of the rooting zone (i.e. $0-10 \mathrm{~cm}$ depth in premontane forest, lower montane forest and montane grasslands; $0-15 \mathrm{~cm}$ in upper montane forest) (Girardin et al., 2010; Zimmermann et al., 2010a), following established protocols (Templer et al., 2005). Samples were collected at monthly intervals (where possible) for determination of monthly timeaveraged $\mathrm{NH}_{4}^{+}, \mathrm{NO}_{3}^{-}$and $\mathrm{NO}_{2}^{-}$concentrations. For some plots, this sampling frequency was periodically disrupted due to natural hazards (i.e. land slides, river flooding) preventing safe access to the study sites. Resin bags were shipped to the University of Aberdeen after collection from the field, inorganic $\mathrm{N}$ was extracted using $2 \mathrm{~N} \mathrm{KCl}$ (Templer et al., 2005) and concentrations determined colorimetrically using a Burkard SFA2 continuous-flow analyser (Burkard Scientific Ltd., Uxbridge, UK). 
Table 2. Summary of soil sampling scheme for denitrification potential experiment.

\begin{tabular}{llllll}
\hline $\begin{array}{l}\text { Elevation } \\
\text { Band } \\
\text { (m a.s.1.) }\end{array}$ & Habitat & Rooting & Soil Sample & $\begin{array}{l}\text { Zone Depth } \\
(\mathrm{cm})\end{array}$ & $\begin{array}{l}\text { Depth } \\
(\mathrm{cm})\end{array}$ \\
\hline $600-1200$ & Premontane forest & 11 & 19 & $0-10$ & $5-10$ \\
$1200-2200$ & Lower montane forest & 2 & 3 & $0-25$ & $20-25$ \\
$2200-3200$ & Upper montane forest & 3 & 5 & $0-25$ & $20-25$ \\
$3200-3700$ & Montane grasslands & 6 & 10 & $0-10$ & $5-10$ \\
\hline
\end{tabular}

\subsection{Denitrification potentials and $\mathrm{N}_{2} \mathrm{O}$ yields}

Potential denitrification rates across the elevation sequence were determined by performing an exploratory ${ }^{15} \mathrm{~N}$-labelled nitrate $\left({ }^{15} \mathrm{~N}^{-N^{-}}{ }_{3}^{-}\right)$laboratory tracer study (Baggs et al., 2003; Bateman and Baggs, 2005). Details of the soil sampling scheme for this experiment are summarized in Table 2. Twenty-two soil samples (125-170 g dry soil per sample) were collected from the same depth as the soil resin bags from sites across the elevation sequence, air-dried and then shipped to the UK by courier. A potential caveat associated with collecting soils from just below the zone of highest root density is that it may lead to underestimates of overall rates of denitrification (due to lower labile $\mathrm{C}$ availability) or overestimates of $\mathrm{N}_{2} \mathrm{O}$ production rates (as higher labile $\mathrm{C}$ availability in the zone of greatest root density may promote denitrification to $\mathrm{N}_{2}$ ) (Davidson, 1991; Firestone et al., 1980; Weier et al., 1993). However, given evidence for the overarching role of $\mathrm{NO}_{3}^{-}$availability in regulating $\mathrm{N}_{2} \mathrm{O}$ fluxes across this elevation gradient (see below), we chose to sample soils from the same depths as our measured indices of $\mathrm{NO}_{3}^{-}$(i.e. the soil resin bags), thus enabling us to better establish possible linkages between $\mathrm{NO}_{3}^{-}$availability and microbial denitrification potential. Moreover, because the soils were collected on a similar basis, results from the potential denitrification experiment are comparable across study sites, enabling us to probe for relative differences among habitats.

Upon arrival in the UK, $50 \mathrm{~g}$ dry soil sub-samples were taken from each soil sample and weighed out into $52700 \mathrm{~mL}$ glass vessels for incubation ( $n=19$ for premontane forest, $n=3$ for lower montane forest, $n=5$ for upper montane forest, $n=10$ for montane grasslands). The uneven sample sizes reflect the fact that this experiment was designed as a preliminary scoping exercise to capture a broad range of environmental conditions, microtopographic and mesotopic features in order to quantify the range of variability in denitrification rates both within and among habitats. Soil subsamples were initially re-wetted to $20 \%$ volumetric water content, and allowed to pre-incubate for four days. Soils were further moistened at the start of the experiment to achieve a final WFPS of $80 \%$. A $\mathrm{KNO}_{3}$ solution containing $0.2 \mathrm{~mL}$ of $0.01 \mathrm{M} 40$ atom $\%{ }^{15} \mathrm{~N}_{-\mathrm{NO}_{3}^{-}}$was then added to the soil, and the glass incubation vessels sealed to initiate the exper- iment. Control incubations were conducted with soils from each habitat ( $n=3$ per elevation) to correct for the ${ }^{15} \mathrm{~N}$ natural abundance signature of endogenous $\mathrm{N}_{2} \mathrm{O}$ and $\mathrm{N}_{2}$ production. Gas samples were collected at $0,6,12,24,33$ and 48 hours to quantify $\mathrm{N}_{2} \mathrm{O},{ }^{15} \mathrm{~N}-\mathrm{N}_{2} \mathrm{O}$ and ${ }^{15} \mathrm{~N}-\mathrm{N}_{2}$ concentrations. Gas concentrations and isotope ratios were determined at the University of Aberdeen, using an Agilent 6890 GC fitted with an ECD (Agilent Technologies UK Ltd., Workingham, UK) and a SerCon 20:20 isotope ratio mass spectrometer (IRMS) equipped with an ANCA TGII pre-concentration module (SerCon Ltd., Crewe, UK), respectively. Instrumental precision was determined by repeated analysis of standards and was better than $5 \%$ for both the GC and IRMS. Potential denitrification rates were calculated from the difference in the ${ }^{15} \mathrm{~N}$ atom $\%$ excess values of $\mathrm{N}_{2} \mathrm{O}$ and $\mathrm{N}_{2}$ relative to the controls. Fluxes of ${ }^{15} \mathrm{~N}-\mathrm{N}_{2} \mathrm{O}$ and ${ }^{15} \mathrm{~N}-\mathrm{N}_{2}$ were determined using the R (R Core Team; http://www.r-project.org) HMR package (as described above) and normalized for soil dry weight. Total denitrification potential (i.e. sum of ${ }^{15} \mathrm{~N}$ $\mathrm{N}_{2} \mathrm{O}$ plus ${ }^{15} \mathrm{~N}-\mathrm{N}_{2}$ fluxes) and $\mathrm{N}_{2} \mathrm{O}$ yield (i.e. the ratio of ${ }^{15} \mathrm{~N}-\mathrm{N}_{2} \mathrm{O}:{ }^{15} \mathrm{~N}-\mathrm{N}_{2} \mathrm{O}$ flux $+{ }^{15} \mathrm{~N}-\mathrm{N}_{2}$ flux) were also calculated (Yang et al., 2011).

\subsection{Statistical analyses}

Statistical analyses were performed using JMP IN Version 8 (SAS Institute, Inc., Cary, North Carolina, USA) and R (R Core Team, 2012). The data were transformed where necessary to meet the assumptions of analysis of variance. Residuals were checked for heteroscedasticity and homogeneity of variances. Non-parametric tests were performed where transformed data were non-normally distributed or heteroscedastic. Generalized Linear Models (GLMs) were used to determine the influence of spatial (e.g. habitat, landform) and temporal factors (e.g. day of year, season) on gas fluxes and environmental variables. GLMs were also used to evaluate the collective contribution of categorical independent variables (habitat, landform, day of year, season) and continuous independent variables (soil moisture, soil oxygen, soil temperature, air temperature) in regulating trace gas fluxes. To determine if fluxes varied significantly among habitats, landforms or seasons, we used one-way ANOVA or Student's $t$ tests for normally distributed data with equal variances, while Kruskal-Wallis ANOVA or Wilcoxon signed-rank test were 
Table 3. Abiotic environmental variables for each habitat for the wet and dry season. Upper case letters indicate differences among habitats and lower case letters indicate difference among seasons within habitats (Fisher's LSD, $P<0.05$ ). Values reported here are means and standard errors.

\begin{tabular}{|c|c|c|c|c|c|c|c|c|c|c|c|}
\hline \multirow[t]{2}{*}{$\begin{array}{l}\text { Elevation Band } \\
\text { (m a.s.l.) }\end{array}$} & \multirow[t]{2}{*}{ Habitat } & \multicolumn{2}{|c|}{$\begin{array}{l}\text { Volumetric Soil Moisture } \\
\qquad(\%)\end{array}$} & \multicolumn{2}{|c|}{$\begin{array}{l}\text { Water-filled pore space } \\
\qquad(\%)\end{array}$} & \multicolumn{2}{|c|}{$\begin{array}{l}\text { Soil Oxygen } \\
(\%)\end{array}$} & \multicolumn{2}{|c|}{$\begin{array}{c}\text { Soil Temperature } \\
\left({ }^{\circ} \mathrm{C}\right)\end{array}$} & \multicolumn{2}{|c|}{$\begin{array}{l}\text { Air Temperature } \\
\left({ }^{\circ} \mathrm{C}\right)\end{array}$} \\
\hline & & Wet Season & Dry Season & Wet Season & Dry Season & Wet Season & Dry Season & Wet Season & Dry Season & Wet Season & Dry Season \\
\hline & & $.3 \pm 2.4 \mathrm{~A} \mathrm{a}$ & & & & & & & & & \\
\hline & & & & & & & & & & & \\
\hline & forest & $7.7 \pm 1.0 \mathrm{~A} \mathrm{~b}$ & $22.7 \pm$ & $68.6 \pm 1.9 \mathrm{~A} \mathrm{~b}$ & $41.2 \pm$ & $2 \mathrm{Aa}$ & $18.5 \pm$ & $12.0 \pm 0.1 \mathrm{Ca}$ & $0.1 \mathrm{C} \mathrm{b}$ & $12.7 \pm 0.1 \mathrm{C} \mathrm{a}$ & $13.2 \pm 0.1 \mathrm{Cb}$ \\
\hline $3200-3700$ & Montane grasslands & $71.6 \pm 0.5 \mathrm{~B} \mathrm{a}$ & $71.2 \pm 0.5 \mathrm{D} \mathrm{a}$ & $95.5 \pm 0.2 \mathrm{~B} \mathrm{a}$ & $92.9 \pm 0.7 \mathrm{D} \mathrm{b}$ & $13.3 \pm 0.4 \mathrm{~B} \mathrm{a}$ & $18.4 \pm 0.1 \mathrm{~B} \mathrm{~b}$ & $10.2 \pm 0.1 \mathrm{Da}$ & $9.7 \pm 0.1 \mathrm{D} \mathrm{b}$ & $11.3 \pm 0.2 \mathrm{D} \mathrm{a}$ & $12.5 \pm 0.3 \mathrm{Cb}$ \\
\hline
\end{tabular}
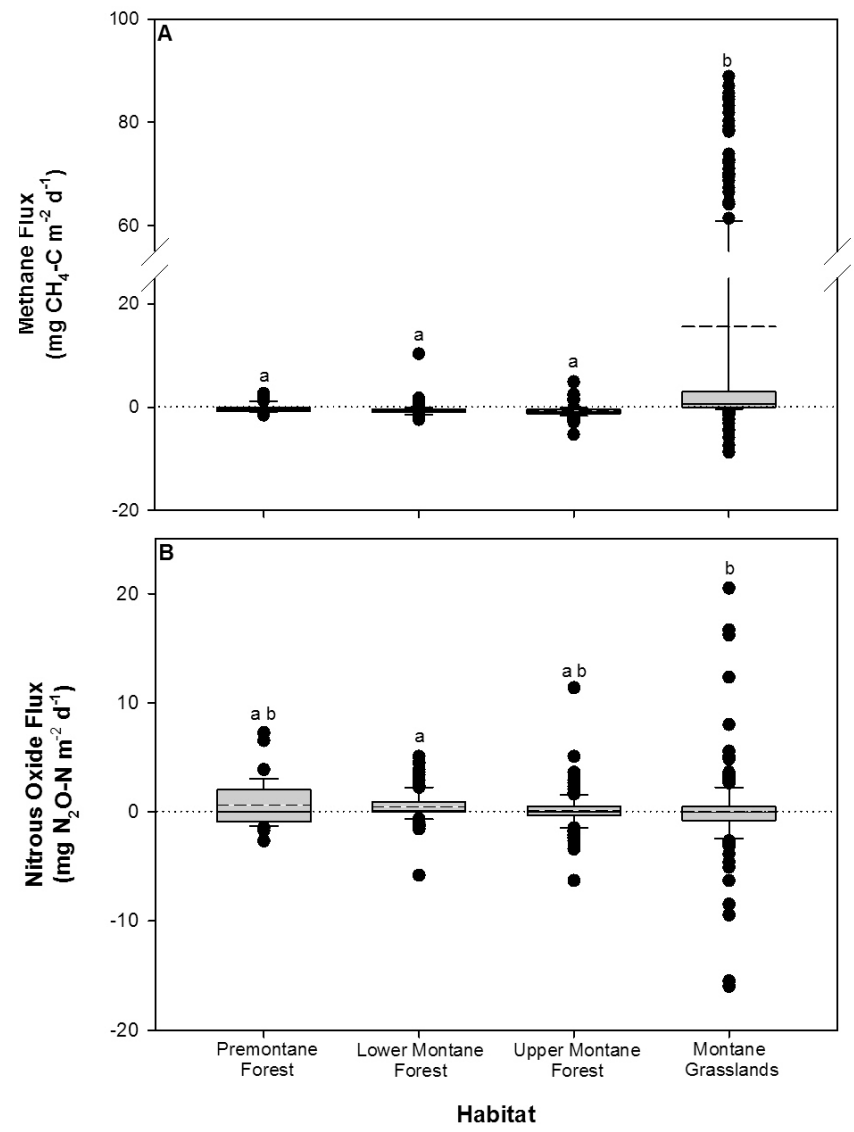

Fig. 2. (A) $\mathrm{Net}^{\mathrm{CH}_{4}}$ and (B) net $\mathrm{N}_{2} \mathrm{O}$ fluxes by habitat. The shortdash line within each box represents the mean, whereas the solid line represents the median. Boxes enclose the interquartile range, whiskers indicate the 90th and 10th percentiles. The dotted line running across the boxes indicates zero net flux. Kruskal-Wallis ANOVA $(P<0.05)$ was used to test for differences among habitats. Lower case letters indicate statistically significant differences among means (Fisher's LSD on rank transformed data, $P<0.05$ ).

used for data that violated assumptions of normality and uniformity of variances. Relationships among continuous independent environmental variables and trace gas fluxes were investigated using linear regression for normally distributed data with equal variances, while Poisson regression or Spearman's Rank correlation were used to analyse non-normally distributed, heteroscedastic data. Means comparisons were performed using Fisher's Least Significant Difference test (Fisher's LSD). Statistical significance was determined at the $P<0.05$ level, unless otherwise noted. Values are reported as means and standard errors $( \pm 1 \mathrm{SE})$

\section{Results}

\subsection{Spatial variation in gas fluxes and environmental variables}

The mean soil $\mathrm{CH}_{4}$ flux for the entire 13-month data set was $7.79 \pm 1.14 \mathrm{mg} \mathrm{CH}_{4}-\mathrm{Cm}^{-2} \mathrm{~d}^{-1}$. Soil $\mathrm{CH}_{4}$ fluxes varied significantly among habitats and over time (GLM, $P<0.0001)$. Multiple comparisons tests indicated that soil $\mathrm{CH}_{4}$ flux from montane grasslands differed significantly from other habitats (Fisher's LSD, $P<0.05$; Fig. 2a). Montane grasslands were net sources of $\mathrm{CH}_{4}$, with a mean flux of $15.60 \pm 2.14 \mathrm{mg} \mathrm{CH} \mathrm{CH}_{4}-\mathrm{C} \mathrm{m}^{-2} \mathrm{~d}^{-1}$. In contrast, premontane, lower montane and upper montane forests were all net atmospheric sinks, with mean fluxes of $-0.16 \pm 0.13$, $-0.64 \pm 0.08$ and $-0.82 \pm 0.08 \mathrm{mg} \mathrm{CH}_{4}-\mathrm{C} \mathrm{m}^{-2} \mathrm{~d}^{-1}$, respectively (Fig. 2a). Soil $\mathrm{CH}_{4}$ fluxes varied significantly among landforms (Kruskal-Wallis ANOVA, $P<0.0001$; data not shown). Basin landforms, found only in montane grasslands, emitted significantly more $\mathrm{CH}_{4}$ than other landforms (mean $\mathrm{CH}_{4}$ flux for basin landforms was $63.99 \pm 7.80 \mathrm{mg} \mathrm{CH}_{4}-$ $\mathrm{C} \mathrm{m}^{-2} \mathrm{~d}^{-1}$; Fisher's LSD, $P<0.05$; data not shown). Other landforms were either weak sources or sinks, but could not be distinguished from each other statistically because of the large variance in fluxes. The mean for pooled soil $\mathrm{CH}_{4}$ fluxes from ridge, slope and flat landforms (i.e. the entire data set excluding basin landforms) was $0.47 \pm 0.18 \mathrm{mg}$ $\mathrm{CH}_{4}-\mathrm{C} \mathrm{m}^{-2} \mathrm{~d}^{-1}$, with a range from -8.71 to $78.5 \mathrm{mg} \mathrm{CH}_{4}-$ $\mathrm{C} \mathrm{m}^{-2} \mathrm{~d}^{-1}$.

The mean soil $\mathrm{N}_{2} \mathrm{O}$ flux for the entire 13-month data set was $0.22 \pm 0.12 \mathrm{mg} \mathrm{N} \mathrm{N}_{2} \mathrm{O}-\mathrm{N} \mathrm{m}^{-2} \mathrm{~d}^{-1}$. $\mathrm{N}_{2} \mathrm{O}$ fluxes varied widely among habitats and over time (GLM, $P<0.05$ ). Mean $\mathrm{N}_{2} \mathrm{O}$ fluxes declined progressively with increasing elevation (Kruskal-Wallis ANOVA, $P<0.05$ ), with the highest fluxes observed in premontane forest $\left(0.61 \pm 0.36 \mathrm{mg} \mathrm{N}_{2} \mathrm{O}-\mathrm{N} \mathrm{m}^{-2} \mathrm{~d}^{-1}\right)$, followed by lower montane forest $\left(0.46 \pm 0.12 \mathrm{mg} \mathrm{N}_{2} \mathrm{O}-\mathrm{N} \mathrm{m}^{-2} \mathrm{~d}^{-1}\right)$, upper montane forest $\left(0.12 \pm 0.13 \mathrm{mg} \mathrm{N}_{2} \mathrm{O}-\mathrm{N} \mathrm{m}^{-2} \mathrm{~d}^{-1}\right)$ and montane grasslands (0.04 $\left.\pm 0.30 \mathrm{mg} \mathrm{N}_{2} \mathrm{O}-\mathrm{N} \mathrm{m}^{-2} \mathrm{~d}^{-1}\right)$ (Fig. 2b). 

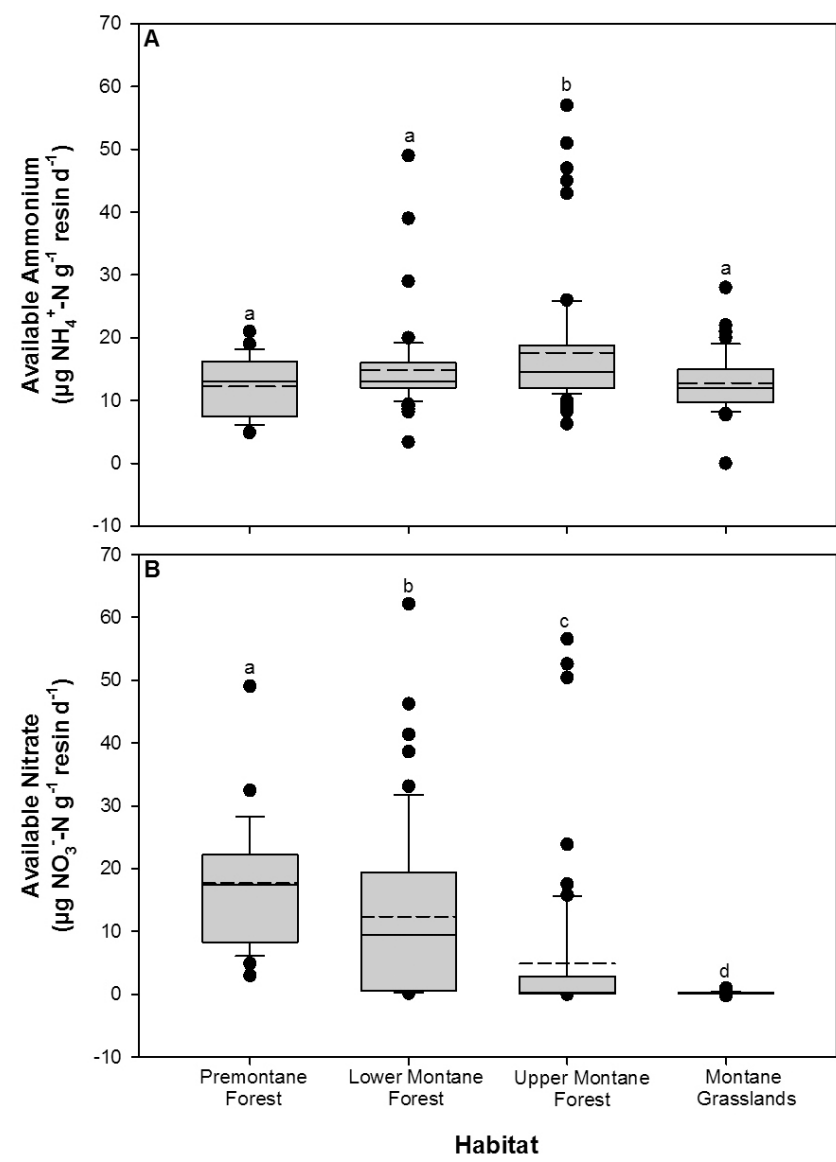

Fig. 3. (A) Available $\mathrm{NH}_{4}^{+}$and (B) available $\mathrm{NO}_{3}^{-}$fluxes by habitat. The short-dash line within each box represents the mean, whereas the solid line represents the median. Boxes enclose the interquartile range, whiskers indicate the 90th and 10th percentiles. Kruskal-Wallis ANOVA $(P<0.05)$ was used to test for differences among habitats. Lower case letters indicate statistically significant differences among means (Fisher's LSD on rank transformed data, $P<0.05)$.

Soil $\mathrm{N}_{2} \mathrm{O}$ fluxes also varied significantly among landforms (Kuskal-Wallis ANOVA, $P<0.05$ ), with highest fluxes from flat landforms $\left(0.58 \pm 0.23 \mathrm{mg} \mathrm{N}_{2} \mathrm{O}\right.$ $\left.\mathrm{N} \mathrm{m}^{-2} \mathrm{~d}^{-1}\right)$, followed by ridges $\left(0.12 \pm 0.25 \mathrm{mg} \mathrm{N} \mathrm{N}_{2} \mathrm{O}\right.$ $\left.\mathrm{N} \mathrm{m}^{-2} \mathrm{~d}^{-1}\right)$, slopes $\left(0.06 \pm 0.18 \mathrm{mg} \mathrm{N}_{2} \mathrm{O}-\mathrm{N} \mathrm{m}^{-2} \mathrm{~d}^{-1}\right)$ and basins $\left(-0.27 \pm 0.62 \mathrm{mg} \mathrm{N}_{2} \mathrm{O}-\mathrm{N} \mathrm{m}^{-2} \mathrm{~d}^{-1}\right)$.

Soil moisture varied significantly among habitats and over time (GLM, $P<0.0001$ ). Multiple comparison tests indicate that soil moisture varied significantly among habitats (Fisher's LSD, $P<0.05$; Table 3). Soil moisture was greatest in montane grasslands (WFPS: $94.7 \pm 0.3 \%$ ) followed by premontane forest (WFPS: $70.1 \pm 2.3 \%$ ). Lower montane forest (WFPS: $58.4 \pm 1.2 \%$ ) and upper montane forest (WFPS: $58.0 \pm 1.6 \%$ ) had significantly lower levels of soil moisture than either montane grasslands or premontane forest. Soil moisture varied significantly among landforms
(Kruskal-Wallis ANOVA, $P<0.0001$ ). Basins and ridges were significantly wetter than other landforms (WFPS: $97.5 \pm 0.2$ and $75.1 \pm 1.9 \%$, respectively; Fisher's LSD, $P<0.05$; data not shown), while slope and flat landforms showed similar levels of soil moisture (WFPS: $66.8 \pm 1.5$ and $70.1 \pm 1.5 \%$, respectively).

Soil $\mathrm{O}_{2}$ concentrations in the $0-10 \mathrm{~cm}$ soil depth varied significantly among habitats and over time (GLM, $P<0.0001$ ). Multiple comparisons tests indicated that soil $\mathrm{O}_{2}$ concentration in montane grasslands was significantly lower than in other habitats (Fisher's LSD, $P<0.05$; Table 3), with a mean value of $13.8 \pm 0.3 \%$. Mean $\mathrm{O}_{2}$ concentrations in premontane, lower montane and upper montane forests were $18.7 \pm 0.3,19.2 \pm 0.1$ and $18.4 \pm 0.1 \%$, respectively. Soil $\mathrm{O}_{2}$ varied significantly among landforms (Kruskal-Wallis ANOVA, $P<0.0001$ ); basin features showed significantly lower $\mathrm{O}_{2}$ than other landforms $(5.3 \pm 0.9 \%$; Fisher's LSD, $P<0.05)$, but other landforms did not differ significantly in $\mathrm{O}_{2}$ concentration in the $0-10 \mathrm{~cm}$ soil depth. The pooled mean $\mathrm{O}_{2}$ concentration for ridge, slope and flat landforms was $17.1 \pm 0.2 \%$, with a range from $0-21 \% \mathrm{O}_{2}$.

Soil and air temperature varied significantly among habitats and over time (GLM, $P<0.00001$ for both soil and air temperature). Multiple comparisons tests indicated that soil and air temperature were significantly different for each habitat (Table 3), with temperatures becoming progressively cooler with increasing elevation (Fisher's LSD, $P<0.05)$. Temperatures were highest in premontane forest (soil: $21.2 \pm 0.1 \mathrm{C}$; air: $23.4 \pm 0.4 \mathrm{C}$ ), followed by lower montane forest (soil: $18.1 \pm 0.1 \mathrm{C}$; air: $18.2 \pm 0.1 \mathrm{C}$ ), upper montane forest (soil: $11.8 \pm 0.0 \mathrm{C}$; air: $13.0 \pm 0.1 \mathrm{C}$ ) and montane grasslands (soil: $10.1 \pm 0.1 \mathrm{C}$; air: $11.8 \pm 0.2 \mathrm{C}$ ).

Available ammonium $\left(\mathrm{NH}_{4}^{+}\right)$or nitrate $\left(\mathrm{NO}_{3}^{-}\right)$concentrations varied significantly among habitats and over time (GLM for $\mathrm{NH}_{4}^{+}, P<0.001$; GLM for $\mathrm{NO}_{3}^{-}, P<0.0001$ ). In contrast, available $\mathrm{NO}_{2}^{-}$concentrations varied widely among habitats and over time, but with no clear spatial or temporal trends (GLM, $P<0.01$ ). For $\mathrm{NH}_{4}^{+}$, multiple comparisons tests indicate that $\mathrm{NH}_{4}^{+}$concentration was greatest for upper montane forest, while other habitats did not differ significantly from each other (Fisher's LSD, $P<0.05$; Fig. 3a). $\mathrm{NH}_{4}^{+}$concentration for the upper montane forest averaged $17.62 \pm 1.33 \mu \mathrm{g} \mathrm{NH}_{4}^{+}-\mathrm{N} \mathrm{g}^{-1}$ resind ${ }^{-1}$; in contrast, $\mathrm{NH}_{4}^{+}$ concentrations from premontane forest, lower montane forest and montane grasslands averaged $12.28 \pm 0.73,14.82 \pm 0.90$ and $12.78 \pm 0.62 \mu \mathrm{g} \mathrm{NH} \mathrm{NH}_{4}^{+}-\mathrm{N} \mathrm{g}^{-1}$ resin d ${ }^{-1}$, respectively. For $\mathrm{NO}_{3}^{-}$, multiple comparisons tests indicate that $\mathrm{NO}_{3}^{-}$concentrations decreased significantly with increasing elevation (Fisher's LSD, $P<0.05$; Fig. $2 b$ ). Mean $\mathrm{NO}_{3}^{-}$concentrations for premontane forest, lower montane forest, upper montane forest and montane grasslands were $17.67 \pm 1.70$, $12.38 \pm 1.87,4.92 \pm 1.57$ and $0.17 \pm 0.02 \mu \mathrm{g} \mathrm{NO} \mathrm{NO}_{3}^{-}-\mathrm{Ng}^{-1}$ resin $\mathrm{d}^{-1}$, respectively. Available $\mathrm{NO}_{2}^{-}$concentrations did 
Table 4. Soil methane and nitrous oxide fluxes for each habitat for the wet and dry season. Lower case letters indicate differences among seasons within habitats (Fisher's LSD, $P<0.05$ ). Numbers reported here are means and standard errors.

\begin{tabular}{|c|c|c|c|c|c|}
\hline \multirow{2}{*}{$\begin{array}{l}\text { Elevation Band } \\
\text { (m a.s.1.) }\end{array}$} & \multirow[b]{2}{*}{ Habitat } & \multicolumn{2}{|c|}{$\begin{array}{c}\text { Methane Flux } \\
\left(\mathrm{mg} \mathrm{CH}-\mathrm{C} \mathrm{m}^{-2} \mathrm{~d}^{-1}\right)\end{array}$} & \multicolumn{2}{|c|}{$\begin{array}{c}\text { Nitrous Oxide Flux } \\
\left(\mathrm{mg} \mathrm{N}_{2} \mathrm{O}-\mathrm{N} \mathrm{m}^{-2} \mathrm{~d}^{-1}\right)\end{array}$} \\
\hline & & Wet Season & Dry Season & Wet Season & Dry Season \\
\hline $600-1200$ & Premontane forest & $0.51 \pm 0.41 \mathrm{a}$ & $-0.32 \pm 0.11 b$ & $-0.15 \pm 0.43 \mathrm{a}$ & $0.96 \pm 0.47 \mathrm{a}$ \\
\hline $1200-2200$ & Lower montane forest & $-0.49 \pm 0.13 \mathrm{a}$ & $-0.84 \pm 0.07 \mathrm{~b}$ & $0.16 \pm 0.13 \mathrm{a}$ & $0.98 \pm 0.23 b$ \\
\hline $2200-3200$ & Upper montane forest & $-0.54 \pm 0.11 \mathrm{a}$ & $-1.22 \pm 0.04 b$ & $0.02 \pm 0.22 \mathrm{a}$ & $0.19 \pm 0.17 \mathrm{a}$ \\
\hline $3200-3700$ & Montane grasslands & $18.57 \pm 2.55 \mathrm{a}$ & $0.97 \pm 0.47 \mathrm{~b}$ & $-0.61 \pm 0.37 \mathrm{a}$ & $0.93 \pm 0.50 \mathrm{~b}$ \\
\hline
\end{tabular}

not vary significantly among habitats, averaging $0.02 \pm 0.00$ $\mathrm{NO}_{2}^{-}-\mathrm{Ng}^{-1}$ resin d $\mathrm{d}^{-1}$ across the elevation gradient (data not shown).

\subsection{Temporal variability in gas exchange}

Soil $\mathrm{CH}_{4}$ efflux increased during the wet season (GLM $P<0.0001$; Table 4), although there were no clear directional trends in fluxes within seasons. Furthermore, daily sampling in montane grasslands from 11-22 November 2011 identified no apparent trends in $\mathrm{CH}_{4}$ fluxes at this timescale. Mean soil $\mathrm{CH}_{4}$ flux in montane grasslands rose by a factor of 19 from dry season to wet season, from $0.97 \pm 0.47 \mathrm{mg}$ $\mathrm{CH}_{4}-\mathrm{C} \mathrm{m}^{-2} \mathrm{~d}^{-1}$ in the dry season to $18.57 \pm 2.55 \mathrm{mg} \mathrm{CH}_{4}$ $\mathrm{C} \mathrm{m}^{-2} \mathrm{~d}^{-1}$ (Wilcoxon test, $P<0.0001$ ). Likewise net $\mathrm{CH}_{4}$ fluxes became more positive from dry season to wet season for all the other forested habitats (Table 4); the pooled mean for dry season fluxes for the three forest types was $-0.86 \pm 0.05 \mathrm{mg} \mathrm{CH}_{4}-\mathrm{Cm}^{-2} \mathrm{~d}^{-1}$, while the pooled mean for wet season fluxes was $-0.47 \pm 0.08 \mathrm{mg} \mathrm{\textrm {CH } _ { 4 }}$ $\mathrm{C} \mathrm{m}^{-2} \mathrm{~d}^{-1}$ (Wilcoxon test, $P<0.0001$ ). This pattern was most pronounced for premontane forest (Wilcoxon test, $P<0.001$ ), where the direction of the soil-atmosphere flux was reversed from a weak atmospheric sink in the dry season $\left(-0.32 \pm 0.11 \mathrm{mg} \mathrm{CH}_{4}-\mathrm{Cm}^{-2} \mathrm{~d}^{-1}\right)$ to a net atmospheric source during the wet season $\left(0.51 \pm 0.41 \mathrm{mg} \mathrm{CH}_{4}\right.$ $\left.\mathrm{C} \mathrm{m}^{-2} \mathrm{~d}^{-1}\right)$.

For the entire data set as a whole, soil $\mathrm{N}_{2} \mathrm{O}$ fluxes showed the opposite trend to $\mathrm{CH}_{4}$, with net fluxes declining during the wet season (Wilcoxon test, $P<0.005$ ). However, actual seasonal trends varied among habitats; only fluxes in lower montane forest and montane grasslands changed significantly between seasons (Wilcoxon tests, $P<0.001$ and $P<0.05$, respectively), whereas fluxes in premontane and upper montane forests did not (Table 4).

\subsection{Temporal variability in environmental variables}

Across the elevation gradient, soil moisture changed significantly over time, with temporal trends that varied depending on habitat (GLM, $P<0.0001)$. Soil moisture in premontane forest and montane grasslands showed significant month-tomonth variability, but did not differ significantly between seasons (Table 3). In contrast, soil moisture in lower montane and upper montane forest rose significantly from dry season to wet season, with upper montane forest showing a more pronounced shift in soil water content.

Temporal patterns in soil $\mathrm{O}_{2}$ concentrations varied depending on habitat. For lower montane forest, soil $\mathrm{O}_{2}$ varied significantly from month-to-month, with small but statistically higher soil $\mathrm{O}_{2}$ observed in the wet season $(19.4 \pm 0.1 \%)$ compared to the dry season $(19.0 \pm 0.1 \%)$ (Wilcoxon test, $P<0.001$; Table 3). Upper montane forest showed significant month-to-month variability, but no significant differences between seasons (overall mean $=18.4 \pm 0.1 \%)$. Montane grasslands showed a different trend from the other habitats, as lower $\mathrm{O}_{2}$ concentrations were observed during the wet season $(13.3 \pm 0.4 \%)$ compared to the dry season $(18.4 \pm 0.1 \%$ ) (Wilcoxon test, $P<0.0001$; Table 3). Data in the premontane forest site was too sparse to evaluate seasonal patterns in soil $\mathrm{O}_{2}$ content due to unanticipated delays in the installation of soil gas sampling equipment.

Soil temperature and air temperature varied significantly over time (GLM, $P<0.00001$ for both soil and air temperature). In premontane, lower montane and upper montane forests, the overall trend was towards significantly warmer soil and air temperatures during the wet season (Table 3). Montane grasslands showed a different pattern from the other study sites; no significant seasonal differences in soil temperature were observed, while air temperatures were warmer in the dry season $\left(12.5 \pm 0.3^{\circ} \mathrm{C}\right)$ compared to the wet season $\left(11.3 \pm 0.2^{\circ} \mathrm{C}\right.$ ) (Wilcoxon test, $P<0.005$; Table 3 )

There was insufficient data to fully characterize and evaluate seasonal trends in $\mathrm{NH}_{4}^{+}, \mathrm{NO}_{3}^{-}$and $\mathrm{NO}_{2}^{-}$concentrations as only four months of data were collected over the sampling period. However, significant month-to-month variability was observed in $\mathrm{NH}_{4}^{+}, \mathrm{NO}_{3}^{-}$and $\mathrm{NO}_{2}^{-}$concentrations.

\subsection{Relationships between gas fluxes and environmental variables}

Soil $\mathrm{CH}_{4}$ fluxes across the elevation gradient were positively correlated with soil moisture (WFPS: Spearman's $\rho=0.63$, $P<0.0001$; data not shown) and negatively correlated with soil $\mathrm{O}_{2}$ (Spearman's $\rho=-0.45, P<0.0001$, Fig. 4). The net 


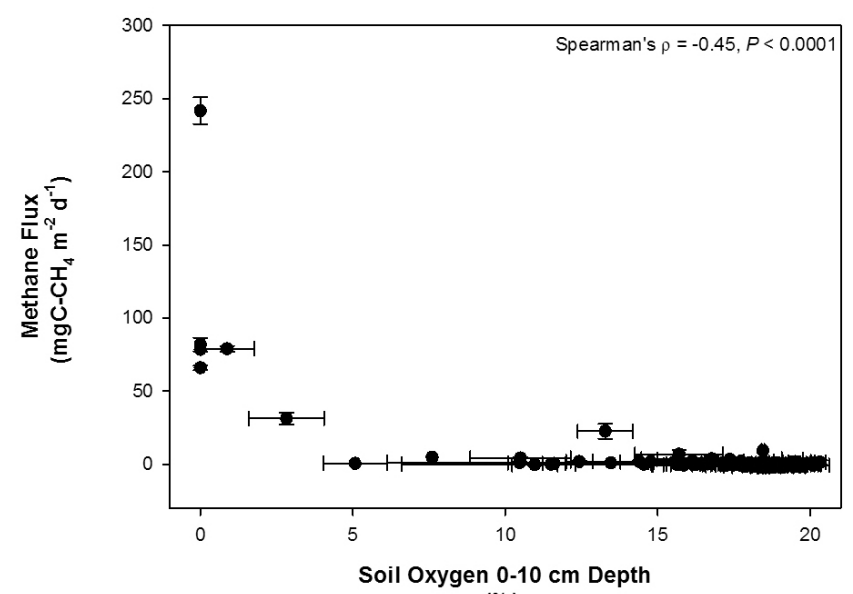

$(\%)$

Fig. 4. Mean plot-level $\mathrm{CH}_{4}$ flux against mean plot-level soil $\mathrm{O}_{2}$ for the $0-10 \mathrm{~cm}$ soil depth. Bars indicate standard errors.

soil $\mathrm{CH}_{4}$ flux-soil $\mathrm{O}_{2}$ relationship shows clear evidence of a threshold effect. From 5-21\% soil $\mathrm{O}_{2}, \mathrm{CH}_{4}$ efflux is low, whereas emissions begin to rise steeply below $5 \%$ soil $\mathrm{O}_{2}$ (Fig. 4). When soil $\mathrm{CH}_{4}$ fluxes were disaggregated by habitat and season, other relationships emerged, suggesting more habitat-specific controls on soil $\mathrm{CH}_{4}$ flux. For example, for lower montane forest, soil $\mathrm{CH}_{4}$ fluxes were negatively correlated with soil temperature during the dry season (Spearman's $\rho=-0.64, P<0.01$ ), but not during the wet season.

Only dry season soil $\mathrm{N}_{2} \mathrm{O}$ fluxes from lower montane forest showed any relationship with environmental variables, with $\mathrm{N}_{2} \mathrm{O}$ fluxes negatively correlated with soil moisture (Spearman's $\rho=-0.41, P<0.1$, data not shown). No other trends were found for other habitats or seasons, whether these data were pooled across the entire elevation gradient, or disaggregated by habitat and season. There were insufficient data on $\mathrm{NH}_{4}^{+}, \mathrm{NO}_{3}^{-}$and $\mathrm{NO}_{2}^{-}$concentrations to statistically determine if inorganic $\mathrm{N}$ fluxes were directly linked to soil $\mathrm{N}_{2} \mathrm{O}$ emissions.

\subsection{Denitrification potentials and $\mathrm{N}_{2} \mathrm{O}$ yields}

Analysis of variance indicated that ${ }^{15} \mathrm{~N}-\mathrm{N}_{2} \mathrm{O},{ }^{15} \mathrm{~N}-\mathrm{N}_{2}$ and total denitrification (i.e. ${ }^{15} \mathrm{~N}-\mathrm{N}_{2} \mathrm{O}+{ }^{15} \mathrm{~N}-\mathrm{N}_{2}$ flux) fluxes varied significantly among habitats (Kruskal-Wallis ANOVA for $\mathrm{N}_{2} \mathrm{O}, P<0.05$; Kruskal-Wallis ANOVA for $\mathrm{N}_{2}, P<0.05$; Kruskal-Wallis ANOVA for total denitrification, $P<0.1$ ). The broad overall trend is that upper montane forest showed the lowest fluxes of ${ }^{15} \mathrm{~N}-\mathrm{N}_{2} \mathrm{O},{ }^{15} \mathrm{~N}-\mathrm{N}_{2}$ and total denitrification, whereas lower montane forest showed the highest fluxes of ${ }^{15} \mathrm{~N}-\mathrm{N}_{2} \mathrm{O}$ and total denitrification (the latter driven by the high ${ }^{15} \mathrm{~N}-\mathrm{N}_{2} \mathrm{O}$ component flux). Premontane forest and montane grasslands showed intermediate fluxes of ${ }^{15} \mathrm{~N}-\mathrm{N}_{2} \mathrm{O}$, ${ }^{15} \mathrm{~N}-\mathrm{N}_{2}$ and total denitrification.

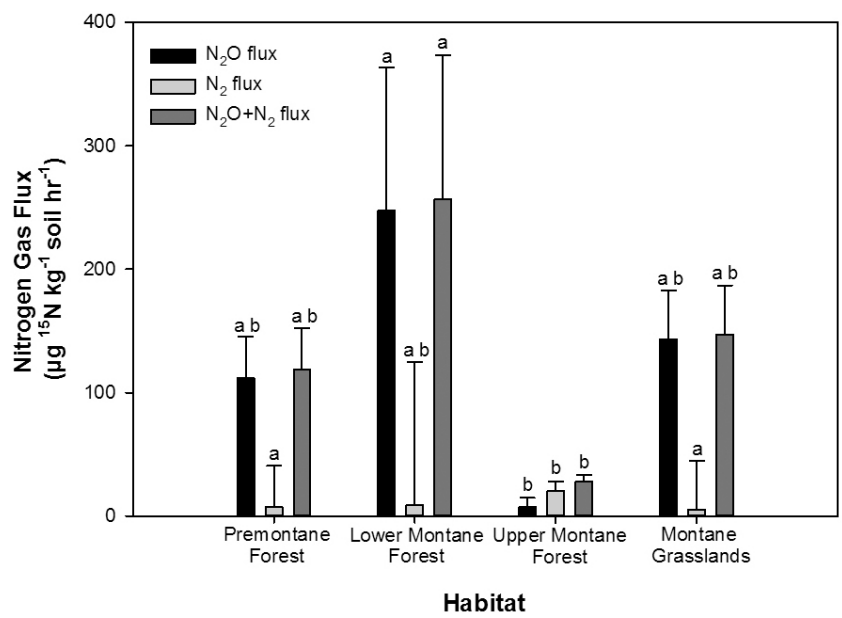

Fig. 5. Potential rates of $\mathrm{N}_{2} \mathrm{O}$ production, $\mathrm{N}_{2}$ production and total $\left(\mathrm{N}_{2} \mathrm{O}+\mathrm{N}_{2}\right)$ denitrification from ${ }^{15} \mathrm{~N}^{-\mathrm{NO}_{3}^{-}}$laboratory tracer studies. Kruskal-Wallis ANOVA $(P<0.05)$ was used to test for differences among habitats. Lower case letters indicate statistically significant differences among means (Fisher's LSD on rank transformed data, $P<0.05)$.

For ${ }^{15} \mathrm{~N}-\mathrm{N}_{2} \mathrm{O}$ flux (Fig. 5), premontane forest and montane grasslands showed comparable fluxes. Lower montane forest showed the highest flux, while upper montane forest showed the lowest. ${ }^{15} \mathrm{~N}-\mathrm{N}_{2} \mathrm{O}$ flux for lower montane forest was significantly greater than those for upper montane forest, but within a similar range to premontane forest and montane grasslands (Fisher's LSD, $P<0.05$ ).

For ${ }^{15} \mathrm{~N}-\mathrm{N}_{2}$ flux (Fig. 5), premontane forest, lower forest and montane grasslands showed comparable fluxes. ${ }^{15} \mathrm{~N}-$ $\mathrm{N}_{2}$ flux was significantly greater for upper montane forest compared to premontane forest or montane grasslands, but within a similar range to lower montane forest (Fisher's LSD, $P<0.05)$.

Total denitrification flux was highest for lower montane forest, lowest in upper montane forest, and at intermediate levels for premontane forest and montane grasslands. Only lower montane forest and upper montane forest showed significant differences in fluxes (Fisher's LSD, $P<0.05$ ). $\mathrm{N}_{2} \mathrm{O}$ yields (i.e. ratio of ${ }^{15} \mathrm{~N}-\mathrm{N}_{2} \mathrm{O}:{ }^{15} \mathrm{~N}-\mathrm{N}_{2} \mathrm{O}$ flux $+{ }^{15} \mathrm{~N}-$ $\mathrm{N}_{2}$ flux) varied significantly among habitats (Kruskal-Wallis ANOVA, $P<0.05$; data not shown). Premontane forest, lower montane forest and montane grasslands had statistically similar $\mathrm{N}_{2} \mathrm{O}$ yields (pooled mean of $0.79 \pm 0.36$ ), whereas upper montane forest showed the lowest $\mathrm{N}_{2} \mathrm{O}$ yield overall $(0.18 \pm 0.40$; Fisher's LSD, $P<0.05)$. 


\section{Discussion}

\subsection{Andean ecosystems as both atmospheric sources and sinks of $\mathrm{CH}_{4}$}

Ecosystems across this tropical elevation-gradient functioned as both atmospheric sources and sinks of $\mathrm{CH}_{4}$, further challenging the long-standing assumption that tropical uplands are only net atmospheric $\mathrm{CH}_{4}$ sinks (Dutaur and Verchot, 2007; Potter et al., 1996; Ridgwell et al., 1999; Teh et al., 2005; von Fischer and Hedin, 2002; Martinson et al., 2010; Covey et al., 2012; Pangala et al., 2013). Soil $\mathrm{CH}_{4}$ fluxes varied depending on elevation, landform and season. Montane grasslands (3200-3700 ma.s.l.) were net atmospheric sources; upper montane and lower montane forests were net sinks; and premontane forest fluctuated between source or sink depending on the season. From 600-3200 m a.s.l., the sink strength for atmospheric $\mathrm{CH}_{4}$ increased with elevation. This pattern runs counter to observations from elsewhere in Latin America, such as Puerto Rico or Ecuador, where net $\mathrm{CH}_{4}$ uptake decreased with increasing elevation (Silver et al., 1999; Teh et al., 2005; Wolf et al., 2012). The divergence between this study and others is likely due to local and regional differences in precipitation and soil moisture retention. Rainfall and soil moisture content decreases with rising elevation in this part of the Andes (Girardin et al., 2010), with the notable exception of montane grasslands, where soil moisture is elevated relative to other habitats across this elevation gradient due to low relief and poor drainage. In contrast, because of regional differences in climate and meteorology, soil moisture increases with elevation in Puerto Rico and Ecuador, favouring greater soil anaerobiosis, enhanced methanogenesis and diminished methanotrophy with rising altitude (Silver et al., 1999; Teh et al., 2005; Wolf et al., 2012).

Soil $\mathrm{CH}_{4}$ fluxes within habitats varied with landforms, with those in lower topographic positions (e.g. basins) emitting more $\mathrm{CH}_{4}$ than those higher up (e.g. ridges). The development of more suboxic conditions in lower topographic positions likely drives greater methanogenesis and reduced methanotrophy, a common pattern observed in many other $\mathrm{CH}_{4}$-emitting ecosystems (Teh et al., 2011; von Fischer et al., 2010; Waddington and Roulet, 1996; Silver et al., 1999). Across the entire altitudinal gradient, basins in montane grasslands emitted more $\mathrm{CH}_{4}$ than any other landform, releasing $233.56 \pm 28.47 \mathrm{~kg} \mathrm{CH}_{4}-\mathrm{C} \mathrm{ha}^{-1} \mathrm{yr}^{-1}$. Our findings are in general agreement with studies in Puerto Rico, where higher net soil $\mathrm{CH}_{4}$ fluxes were observed from lower topographic positions (Silver et al., 1999); but differs from research in Ecuador, where no significant difference was found in net soil $\mathrm{CH}_{4}$ fluxes among landforms within an altitudinal band (Wolf et al., 2012). The most likely explanation for this divergence between the Peruvian and Puerto Rican transects on one hand, and the Ecuadorian transect on the other, is that the investigators in the latter study sampled only ridge and slope landforms, and did not sample landforms in lower topographic positions such as flats or basins, presumably because they were less common across this study site (Wolf et al., 2012). In addition, Wolf et al. (2012) did not sample more water-saturated montane grasslands. Landforms in lower topographic positions and montane grasslands tend to accumulate water and contain more reduced soils capable of emitting $\mathrm{CH}_{4}$, unlike more aerobic ridges and slopes that drain more freely (Teh et al., 2011; von Fischer et al., 2010; Waddington and Roulet, 1996; Silver et al., 1999).

Soil $\mathrm{CH}_{4}$ fluxes varied substantially depending on season, with an overall shift towards greater $\mathrm{CH}_{4}$ emission or significant weakening of net soil sinks during the rainy season. These patterns were most pronounced for montane grasslands and premontane forest; the former showed a nineteen-fold increase in net $\mathrm{CH}_{4}$ efflux from dry season to wet $\left(0.97 \pm 0.47\right.$ to $\left.18.57 \pm 2.55 \mathrm{mg} \mathrm{CH}_{4}-\mathrm{C} \mathrm{m}^{-2} \mathrm{~d}^{-1}\right)$, while the latter switched from a net atmospheric sink $\left(-0.32 \pm 0.11 \mathrm{mg} \mathrm{CH}_{4}-\mathrm{C} \mathrm{m}^{-2} \mathrm{~d}^{-1}\right)$ to a net atmospheric source $\left(0.51 \pm 0.41 \mathrm{mg} \mathrm{CH} \mathrm{CH}_{4}-\mathrm{C} \mathrm{m}^{-2} \mathrm{~d}^{-1}\right)$. These seasonal trends differ significantly from Puerto Rico and Ecuador, where soil $\mathrm{CH}_{4}$ fluxes did not vary strongly on an intraannual basis, presumably because of weaker rainfall seasonality in these other regions (Silver et al., 1999; Teh et al., 2005; Wolf et al., 2012). However, these data are consistent with findings from other seasonally dry tropical ecosystems, where greater net soil $\mathrm{CH}_{4}$ efflux is associated with wetter periods of the year, where soil anaerobiosis is more prevalent (Davidson et al., 2008; Verchot et al., 2000)

Our analysis of spatial, temporal and environmental trends in soil $\mathrm{CH}_{4}$ fluxes across the elevation gradient suggest that soil redox is the principal control on $\mathrm{CH}_{4}$ flux, as is the case elsewhere in the tropics (Teh et al., 2005; Verchot et al., 2000; von Fischer and Hedin, 2007). Soil $\mathrm{CH}_{4}$ emissions were greatest from habitats and landforms where, or during times of year when, soils were at their most suboxic. This conclusion is further supported by the positive correlation between net soil $\mathrm{CH}_{4}$ flux and WFPS, and the negative correlation observed between net soil $\mathrm{CH}_{4}$ flux and soil $\mathrm{O}_{2}$ (Silver et al., 1999; Teh et al., 2005).

\subsection{Andean ecosystems as atmospheric sources of $\mathrm{N}_{2} \mathrm{O}$}

Ecosystems across the Kosñipata Valley were net sources of atmospheric $\mathrm{N}_{2} \mathrm{O}$. Fluxes progressively declined with elevation, with lower elevation habitats emitting substantially greater amounts of soil $\mathrm{N}_{2} \mathrm{O}$ (premontane forest: $2.23 \pm 1.31 \mathrm{~kg} \mathrm{~N}_{2} \mathrm{O}-\mathrm{N} \mathrm{ha}^{-1} \mathrm{yr}^{-1}$; lower montane forest: $\left.1.68 \pm 0.44 \mathrm{~kg} \mathrm{~N}_{2} \mathrm{O}-\mathrm{N} \mathrm{ha}^{-1} \mathrm{yr}^{-1}\right)$ than higher elevation ones (upper montane forest: $0.44 \pm 0.47 \mathrm{~kg} \mathrm{~N} \mathrm{~N}_{2} \mathrm{O}$ $\mathrm{Nha}^{-1} \mathrm{yr}^{-1}$; montane grasslands: $0.15 \pm 1.10 \mathrm{~kg} \mathrm{~N} \mathrm{~N}_{2} \mathrm{O}-$ $\mathrm{Nha}^{-1} \mathrm{yr}^{-1}$ ). Fluxes from lower elevation habitats exceeded the predictions for bottom-up emissions inventories for the region $\left(<0.5-1.0 \mathrm{~kg} \quad \mathrm{~N}_{2} \mathrm{O}-\mathrm{N} \mathrm{ha}^{-1} \mathrm{yr}^{-1}\right)$ (Werner et al., 2007) and were also substantially greater than fluxes observed in Ecuador (mean annual flux of 
Table 5. Preliminary area-weighted flux estimates for the Kosñipata Valley, Manu National Park, Peru. Surface areas and fractional areas calculated from data published in Feeley and Silman (2010). Fluxes values reported here are means and standard errors.

\begin{tabular}{|c|c|c|c|c|c|c|c|}
\hline \multirow[b]{2}{*}{$\begin{array}{l}\text { Elevation Band } \\
\text { (m a.s.l.) }\end{array}$} & \multirow[b]{2}{*}{ Habitat } & \multirow[b]{2}{*}{$\begin{array}{l}\text { Surface Area } \\
\text { (ha) }\end{array}$} & \multirow[b]{2}{*}{ Fractional Area } & \multicolumn{2}{|c|}{ Unweighted Annual Soil Fluxes } & \multicolumn{2}{|c|}{ Area-weighted Annual Soil Fluxes } \\
\hline & & & & $\begin{array}{l}\mathrm{CH}_{4} \\
\mathrm{~kg} \mathrm{CH}_{4}-\mathrm{Cha}^{-1} \mathrm{yr}^{-1}\end{array}$ & $\begin{array}{l}\mathrm{N}_{2} \mathrm{O} \\
\mathrm{kg} \mathrm{N}_{2} \mathrm{O}-\mathrm{Nha}^{-1} \mathrm{yr}^{-1}\end{array}$ & $\begin{array}{l}\mathrm{CH}_{4} \\
\mathrm{~kg} \mathrm{CH}_{4}-\mathrm{Cha}^{-1} \mathrm{yr}^{-1}\end{array}$ & $\begin{array}{l}\mathrm{N}_{2} \mathrm{O} \\
\mathrm{kg} \mathrm{N}_{2} \mathrm{O}-\mathrm{Nha}^{-1} \mathrm{yr}^{-1}\end{array}$ \\
\hline $600-1200$ & Premontane forest & 733000 & 0.24 & $-0.51 \pm 0.47$ & $2.23 \pm 1.31$ & $-0.14 \pm 0.12$ & $0.54 \pm 0.32$ \\
\hline $1200-2200$ & Lower montane forest & 892000 & 0.30 & $-2.34 \pm 0.29$ & $1.68 \pm 0.44$ & $-0.69 \pm 0.09$ & $0.50 \pm 0.13$ \\
\hline $2200-3200$ & Upper montane forest & 807000 & 0.27 & $-2.99 \pm 0.29$ & $0.44 \pm 0.47$ & $-0.80 \pm 0.08$ & $0.12 \pm 0.13$ \\
\hline $3200-3700$ & Montane grasslands & 586000 & 0.19 & $56.94 \pm 7.81$ & $0.15 \pm 1.10$ & $11.05 \pm 1.52$ & $0.03 \pm 0.21$ \\
\hline TOTALS & & 3020000 & 1.00 & & & $9.42 \pm 1.80$ & $1.18 \pm 0.79$ \\
\hline
\end{tabular}

$0.31 \pm 0.12 \mathrm{~kg} \mathrm{~N}_{2} \mathrm{O}-\mathrm{Nha}^{-1} \mathrm{yr}^{-1}$; range of $-0.05-1.27 \mathrm{~kg}$ $\mathrm{N}_{2} \mathrm{O}-\mathrm{N} \mathrm{ha}^{-1} \mathrm{yr}^{-1}$ ) (Wolf et al., 2011). Although the cause for the differences between these observations and prior studies is unclear, it may be linked to the higher $\mathrm{N}$ status of lower elevation soils in the Kosñipata Valley, which tend to be more N-rich than soils in Ecuador (Wolf et al., 2011; Fisher et al., 2013; van de Weg et al., 2009).

Analysis of the field and laboratory data suggests that controls on soil $\mathrm{N}_{2} \mathrm{O}$ fluxes in the Kosñipata Valley are complex and not easily reducible to simple predictive metrics. However, holistic examination of these combined data sets suggests that the availability of $\mathrm{N}$, particularly $\mathrm{NO}_{3}^{-}$, may play a pivotal role in limiting soil $\mathrm{N}_{2} \mathrm{O}$ emissions across the elevation gradient. The central role of $\mathrm{N}$ availability in regulating $\mathrm{N}_{2} \mathrm{O}$ fluxes is highlighted by the altitudinal trends in $\mathrm{N}_{2} \mathrm{O}$ fluxes, available $\mathrm{NO}_{3}^{-}$concentrations, potential $\mathrm{N}_{2} \mathrm{O}$ and $\mathrm{N}_{2}$ production, and ${ }^{15} \mathrm{~N}-\mathrm{N}_{2} \mathrm{O}$ yields. Even though potential denitrification rates were roughly similar across the elevation gradient (with the exception of upper montane forest), net $\mathrm{N}_{2} \mathrm{O}$ fluxes and $\mathrm{NO}_{3}^{-}$availability declined with elevation. Taken together, these data collectively suggest that altitudinal trends in $\mathrm{N}_{2} \mathrm{O}$ fluxes were due to variations in denitrification, driven by differences in $\mathrm{NO}_{3}^{-}$availability. Data on denitrification potential in upper montane forest further reinforces this interpretation of the data; upper montane forest had lower $\mathrm{N}_{2} \mathrm{O}$ production potential, higher $\mathrm{N}_{2}$ production potential and lower $\mathrm{N}_{2} \mathrm{O}$ yields than other sites - all characteristics reflective of $\mathrm{NO}_{3}^{-}$-limitation of denitrification (Blackmer and Bremner, 1978, Weier et al., 1993, Yang et al., 2011). These data are in broad agreement with findings from Ecuador, where $\mathrm{N}$ availability was inversely proportional to altitude and was found to be the dominant control on $\mathrm{N}_{2} \mathrm{O}$ efflux (Wolf et al., 2011).

Soil WFPS appeared to play a more minor role in modulating soil $\mathrm{N}_{2} \mathrm{O}$ fluxes; a surprising finding given the prominent role played by WFPS in regulating soil $\mathrm{N}_{2} \mathrm{O}$ fluxes in other seasonally dry tropical ecosystems (Davidson et al., 2008, Davidson and Verchot, 2000, Davidson et al., 2000, Davidson et al., 1993, Keller and Reiners, 1994). Variations in WFPS only appeared to predict soil $\mathrm{N}_{2} \mathrm{O}$ fluxes in lower montane forest during the dry season, and did not predict $\mathrm{N}_{2} \mathrm{O}$ fluxes in other habitats or during other seasons. This suggests that WFPS did not limit $\mathrm{N}_{2} \mathrm{O}$ production during this 13-month period of observation, and that other factors more strongly constrained $\mathrm{N}_{2} \mathrm{O}$ fluxes in these habitats.

Comprehensive inspection of the environmental data (including soil moisture, WFPS and available N) suggests that the nature of the constraints on $\mathrm{N}_{2} \mathrm{O}$ production differ for each habitat. For premontane forest, lower montane forest and montane grasslands, WFPS fell within a relatively narrow range, making it potentially difficult to identify the "signal" of WFPS relative to background environmental "noise", given the complexity of drivers for $\mathrm{N}_{2} \mathrm{O}$ production (Davidson and Verchot, 2000; Groffman et al., 2009). This signalto-noise problem is further compounded by the fact that WFPS for these habitats falls within the theoretical range where WFPS no longer limits $\mathrm{N}_{2} \mathrm{O}$ production from denitrification (i.e. 60-90\%) (Davidson and Verchot, 2000; Davidson, 1991). As a consequence, $\mathrm{N}_{2} \mathrm{O}$ fluxes no longer increase linearly with WFPS, because denitrification rates are near saturation. The high WFPS for these habitats may also explain the seasonal decrease in $\mathrm{N}_{2} \mathrm{O}$ fluxes from dry to wet season (Table 4); as these wet soils become increasingly waterlogged, denitrification to $\mathrm{N}_{2}$ may be increasingly favoured (Weier et al., 1993). In addition, for montane grasslands, low $\mathrm{NO}_{3}^{-}$availability and high soil $\mathrm{C}$ content may further promote complete denitrification (Blackmer and Bremner, 1978; Davidson, 1991, Weier et al., 1993; Yang et al., 2011; Firestone et al., 1980). In contrast, for upper montane forest, WFPS did in fact vary significantly between seasons (Wilcoxon test, $P<0.0001$; wet season: $68.6 \pm 1.9 \%$; dry season: $41.2 \pm 1.8 \%$ ). However, $\mathrm{N}_{2} \mathrm{O}$ flux in this habitat showed no evident response to changes in WFPS, probably because overall denitrification rates were ultimately constrained by low $\mathrm{NO}_{3}^{-}$availability, and high soil $\mathrm{C}$ content drove denitrification to $\mathrm{N}_{2}$ (Weier et al., 1993; Firestone et al., 1980).

\subsection{Preliminary area-weighted flux estimates for the Kosñipata Valley}

The high mean annual soil $\mathrm{CH}_{4}$ emission from montane grasslands (56.94 $\left.\pm 7.81 \mathrm{~kg} \mathrm{CH}_{4}-\mathrm{Cha}^{-1} \mathrm{yr}^{-1}\right)$ and high mean annual soil $\mathrm{N}_{2} \mathrm{O}$ fluxes from premontane and lower montane forests $\left(2.22 \pm 1.31 \mathrm{~kg} \mathrm{~N} \mathrm{~N}_{2} \mathrm{O}-\mathrm{N} \mathrm{ha}^{-1} \mathrm{yr}^{-1}\right.$ and $1.68 \pm 0.44 \mathrm{~kg} \mathrm{~N}_{2} \mathrm{O}-\mathrm{N} \mathrm{ha}{ }^{-1} \mathrm{yr}^{-1}$, respectively) may mean 
that the Kosñipata Valley is a stronger source for soil $\mathrm{CH}_{4}$ and $\mathrm{N}_{2} \mathrm{O}$ than previously predicted by bottom-up emissions inventories for upland tropical ecosystems in the region. To explore this possibility, we performed simple area-weighted flux calculations to estimate the potential contribution of different habitats to regional $\mathrm{CH}_{4}$ and $\mathrm{N}_{2} \mathrm{O}$ exchange. While we acknowledge that this "back-of-the-envelope" approach is not sufficient to accurately scale up plot-level fluxes to the regional scale, we believe it is still useful as a means of producing first order approximations of the source or sink potential of the region for $\mathrm{CH}_{4}$ and $\mathrm{N}_{2} \mathrm{O}$.

Using published surface area estimates for different habitats for the Kosñipata Valley (Feeley and Silman, 2010), we calculated the areal fractions for each habitat, multiplying these values by the mean annual fluxes of soil $\mathrm{CH}_{4}$ or $\mathrm{N}_{2} \mathrm{O}$ for our study sites, in order to derive area-weighted soil flux estimates for each habitat (Table 5). To estimate the regional atmospheric flux of $\mathrm{CH}_{4}$ or $\mathrm{N}_{2} \mathrm{O}$ (i.e. for the Kosñipata Valley as a whole), we added together the areaweighted soil fluxes from each habitat (Table 5). This exercise produced mean annual flux estimates of $9.42 \pm 1.80 \mathrm{~kg}$ $\mathrm{CH}_{4}-\mathrm{Cha}^{-1} \mathrm{yr}^{-1}$ and $1.18 \pm 0.79 \mathrm{~kg} \mathrm{~N}_{2} \mathrm{O}-\mathrm{Nha}^{-1} \mathrm{yr}^{-1}$, respectively. This approach may underestimate the true emissions potential of these habitats, given that our calculations only accounted for soil-derived fluxes, and did not include estimates of plant-derived fluxes nor emissions from rivers, pools and lakes (Covey et al., 2012; Martinson et al., 2010; Pangala et al., 2013).

The positive sign of the area-weighted soil $\mathrm{CH}_{4}$ flux indicates that the region as whole is probably a net atmospheric $\mathrm{CH}_{4}$ source, strongly influenced by the contribution of montane grasslands acting as a regional "hotspot" for $\mathrm{CH}_{4}$. This speculation is supported by evidence from remote sensing studies showing elevated atmospheric $\mathrm{CH}_{4}$ concentrations in the tropical Andes, implying the presence of strong regional sources, such as waterlogged, suboxic/anoxic montane grasslands (i.e. puna or páramo), unaccounted for by past bottom-up emissions inventories (Wania et al., 2007; Bergamaschi et al., 2007). Likewise the estimated regional soil $\mathrm{N}_{2} \mathrm{O}$ flux for the Kosñipata Valley exceeds both model predictions for the region $\left(<0.5-1.0 \mathrm{~kg} \mathrm{~N}_{2} \mathrm{O}-\mathrm{N} \mathrm{ha}^{-1} \mathrm{yr}^{-1}\right)$ (Werner et al., 2007) and observations from comparable ecosystems in Ecuador (mean annual flux of $0.31 \pm 0.12 \mathrm{~kg}$ $\mathrm{N}_{2} \mathrm{O}-\mathrm{N} \mathrm{ha}^{-1} \mathrm{yr}^{-1}$ ) (Wolf et al., 2011), probably influenced by the strong emissions from lower elevation habitats, which account for $\sim 54 \%$ of overall land cover.

While these area-weighted flux estimates may only be a first approximation, they are significant because these calculations suggest that Andean ecosystems may behave differently than previously thought, and may be larger emission sources than predicted. These findings also highlight the need for more intensive modelling studies to scale up plotlevel measurements to the regional scale in order to more thoroughly evaluate the importance of these ecosystems for regional atmospheric budgets.

\section{Conclusions}

These data suggest that tropical Andean ecosystems are potentially important contributors to regional atmospheric budgets of $\mathrm{CH}_{4}$ and $\mathrm{N}_{2} \mathrm{O}$, and that these ecosystems need to be considered more fully in future efforts to model and scale up $\mathrm{CH}_{4}$ and $\mathrm{N}_{2} \mathrm{O}$ fluxes from the terrestrial tropics. Ecosystems across this tropical elevation-gradient were both atmospheric sources and sinks of $\mathrm{CH}_{4}$, challenging long-standing assumptions from the literature that upland tropical ecosystems are only net atmospheric $\mathrm{CH}_{4}$ sinks. Simple area-weighted flux calculations suggest that high soil $\mathrm{CH}_{4}$ fluxes from emissions "hotspots" (e.g. montane grasslands) may make the region as a whole a net atmospheric $\mathrm{CH}_{4}$ source. This inference is supported by top-down remote sensing data that indicates the existence of strong local $\mathrm{CH}_{4}$ sources in the tropical Andes, leading to enhanced atmospheric $\mathrm{CH}_{4}$ concentrations. Soil $\mathrm{CH}_{4}$ fluxes were modulated by redox dynamics, with the largest emissions arising from habitats and landforms where, or during time periods when, soil $\mathrm{O}_{2}$ availability was lowest or soil WFPS was highest. Ecosystems across this altitudinal gradient were also net atmospheric sources of $\mathrm{N}_{2} \mathrm{O}$, with the largest soil $\mathrm{N}_{2} \mathrm{O}$ emissions originating from lower elevation habitats (premontane forest, lower montane forest). Simple area-weighted flux calculations suggest that this region is likely to be a stronger source of atmospheric $\mathrm{N}_{2} \mathrm{O}$ than previously predicted by bottom-up emissions inventories. This is largely due to the fact that lower elevation habitats are relatively large emission sources, and account for a substantial fraction of total land area in the region $(\sim 54 \%)$. Proximate controls on soil $\mathrm{N}_{2} \mathrm{O}$ fluxes were complex and difficult to elucidate from field measurements alone, although comprehensive inspection of combined field and laboratory data indicate that $\mathrm{NO}_{3}^{-}$availability is the principal constraint on soil $\mathrm{N}_{2} \mathrm{O}$ efflux, while soil moisture and water-filled porosity played a secondary role in modulating emissions. Any current and future changes in $\mathrm{N}$ management or anthropogenic $\mathrm{N}$ deposition may cause shifts in net soil $\mathrm{N}_{2} \mathrm{O}$ fluxes from these tropical montane ecosystems, further enhancing this potentially large emission source.

\section{Supplementary material related to this article is available online at http://www.biogeosciences.net/11/ 2325/2014/bg-11-2325-2014-supplement.zip.}

Acknowledgements. The authors would like to acknowledge the agencies that funded this research; the UK Natural Environment Research Council (NERC; joint grant references NE/H006583, $\mathrm{NE} / \mathrm{H} 007849$ and NE/H006753) and the Norwegian Agency for Development Cooperation (Norad; via a sub-contract to Yit Arn Teh managed by the Amazon Conservation Association). Pete Smith is a Royal Society Wolfson Research Merit Award 
holder and Patrick Meir is supported by an Australian Research Council Fellowship (FT110100457). Javier Eduardo Silva Espejo, Walter Huaraca Huasco, Adan Julian Ccahuana and the ABIDA NGO provided critical fieldwork and logistical support. Angus Calder and Vicky Munro provided invaluable laboratory support. Viktoria Oliver provided data on soil characteristics for Hacienda Villa Carmen. Thanks to Adrian Tejedor from the Amazon Conservation Association, who provided assistance with site access and selection at Hacienda Villa Carmen. Thanks are also owed to $\mathrm{TCH}$ for providing comments on an earlier draft of this manuscript. This publication is a contribution from the Scottish Alliance for Geoscience, Environment and Society (http://www.sages.ac.uk).

Edited by: P. Stoy

\section{References}

Baggs, E. M., Richter, M., Cadisch, G., and Hartwig, U. A.: Denitrification in grass swards is increased under elevated atmospheric $\mathrm{CO}_{2}$, Soil. Biol. Biochem., 35, 729-732, 2003.

Bateman, E. J. and Baggs, E. M.: Contributions of nitrification and denitrification to $\mathrm{N}_{2} \mathrm{O}$ emissions from soils at different waterfilled pore space, Biol. Fertil. Soils, 41, 379-388, 2005.

Belyea, L. R. and Baird, A. J.: Beyond the limits to peat bog growth: Cross-scale feedback in peatland development, Ecol. Monogr., 76, 299-322, 2006.

Bergamaschi, P., Frankenberg, C., Meirink, J. F., Krol, M., Dentener, F., Wagner, T., Platt, U., Kaplan, J. O., Korner, S., Heimann, M., Dlugokencky, E. J., and Goede, A.: Satellite chartography of atmospheric methane from SCIAMACHY onboard ENVISAT: 2. Evaluation based on inverse model simulations, J. Geophys. Res.-Atmos., 112, 1-26, 2007.

Bergamaschi, P., Frankenberg, C., Meirink, J. F., Krol, M., Villani, M. G., Houweling, S., Dentener, F., Dlugokencky, E. J., Miller, J. B., Gatti, L. V., Engel, A., and Levin, I.: Inverse modeling of global and regional $\mathrm{CH}_{4}$ emissions using SCIAMACHY satellite retrievals, J. Geophys. Res.-Atmos., 114, 1-28, 2009.

Blackmer, A. M. and Bremner, J. M.: Inhibitory effect of nitrate on reduction of $\mathrm{N}_{2} \mathrm{O}$ to $\mathrm{N}_{2}$ by soil microorganisms, Soil Biol. Biochem., 10, 187-191, 1978.

Breuer, L., Papen, H., and Butterbach-Bahl, K.: $\mathrm{N}_{2} \mathrm{O}$ emission from tropical forest soils of Australia, J. Geophys. Res.-Atmos., 105, 26353-26367, 2000.

Clark, M., Jarvis, S., and Maltby, E.: An improved technique for measuring concentration of soil gases at depth in situ, Commun. Soil Sci. Plant Anal., 32, 369-377, 2001.

Covey, K. R., Wood, S. A., Warren, R. J., Lee, X., and Bradford, M. A.: Elevated methane concentrations in trees of an upland forest, Geophys. Res. Lett., 39, L15705, 15701-15706, 2012.

Davidson, E. A.: Fluxes of nitrous oxide and nitric oxide from terrestrial ecosystems, in: Microbial production and consumption of greenhouse gases: methane, nitrogen oxides, and halomethanes, edited by: Rogers, J. E., and Whitman, W. B., American Society for Microbiology, Washington DC, 219-236, 1991.

Davidson, E. A., Matson, P. A., Vitousek, P. M., Riley, R., Dunkin, K., Garciamendez, G., and Maass, J. M.: Processes regulating soil emissions of $\mathrm{NO}$ and $\mathrm{N}_{2} \mathrm{O}$ in a seasonally dry tropical forest, Ecology, 74, 130-139, 1993.
Davidson, E. A. and Verchot, L. V.: Testing the Hole-in-the-Pipe Model of nitric and nitrous oxide emissions from soils using the TRAGNET Database, Global Biogeochem. Cy., 14, 1035-1043, 2000.

Davidson, E. A., Verchot, L. V., Cattanio, J. H., Ackerman, I. L., and Carvalho, J. E. M.: Effects of soil water content on soil respiration in forests and cattle pastures of eastern Amazonia, Biogeochemistry, 48, 53-69, 2000.

Davidson, E. A., Nepstad, D. C., Ishida, F. Y., and Brando, P. M.: Effects of an experimental drought and recovery on soil emissions of carbon dioxide, methane, nitrous oxide, and nitric oxide in a moist tropical forest, Glob. Change Biol., 14, 2582-2590, 2008.

Dutaur, L. and Verchot, L. V.: A global inventory of the soil $\mathrm{CH}_{4}$ sink, Global Biogeochem. Cy., 21, 1-9, 2007.

Eva, H. D., Belward, A. S., De Miranda, E. E., Di Bella, C. M., Gond, V., Huber, O., Jones, S., Sgrenzaroli, M., and Fritz, S.: A land cover map of South America, Glob. Change Biol., 10, 731744, 2004.

Feeley, K. J. and Silman, M. R.: Land-use and climate change effects on population size and extinction risk of Andean plants, Glob. Change Biol., 16, 3215-3222, 10.1111/j.13652486.2010.02197.x, 2010.

Firestone, M. K. and Davidson, E. A.: Microbiological basis of $\mathrm{NO}$ and $\mathrm{N}_{2} \mathrm{O}$ production and consumption in soil, Exchange of Trace Gases between Terrestrial Ecosystems and the Atmosphere, edited by: Andreae, M. O. and Schimel, D. S., John Wiley \& Sons, New York, 7-21, 1989.

Firestone, M. K., Firestone, R. B., and Tiedge, J. M.: Nitrous oxide from soil denitrification: Factors controlling its biological production, Science, 208, 749-751, 1980.

Fisher, J. B., Malhi, Y., Torres, I. C., Metcalfe, D. B., van de Weg, M. J., Meir, P., Silva-Espejo, J. E., and Huasco, W. H.: Nutrient limitation in rainforests and cloud forests along a 3000-m elevation gradient in the Peruvian Andes, Oecologia, 172, 889-902, 2013.

Fletcher, S. E. M., Tans, P. P., Bruhwiler, L. M., Miller, J. B., and Heimann, M.: $\mathrm{CH}_{4}$ sources estimated from atmospheric observations of $\mathrm{CH}_{4}$ and its $\mathrm{C}-13 / \mathrm{C}-12$ isotopic ratios: 1 . Inverse modeling of source processes, Global Biogeochem. Cy., 18, 1-17, 2004a.

Fletcher, S. E. M., Tans, P. P., Bruhwiler, L. M., Miller, J. B., and Heimann, M.: $\mathrm{CH}_{4}$ sources estimated from atmospheric observations of $\mathrm{CH}_{4}$ and its $\mathrm{C}-13 / \mathrm{C}-12$ isotopic ratios: 2 . Inverse modeling of $\mathrm{CH}_{4}$ fluxes from geographical regions, Global Biogeochem. Cy., 18, 1-15, 2004b.

Frankenberg, C., Meirink, J. F., van Weele, M., Platt, U., and Wagner, T.: Assessing methane emissions from global space-borne observations, Science, 308, 1010-1014, 2005.

Frankenberg, C., Bergamaschi, P., Butz, A., Houweling, S., Meirink, J. F., Notholt, J., Petersen, A. K., Schrijver, H., Warneke, T., and Aben, I.: Tropical methane emissions: A revised view from SCIAMACHY onboard ENVISAT, Geophys. Res. Lett., 35, 1-5, 2008.

Fung, I., John, J., Lerner, J., Matthews, E., Prather, M., Steele, L., and Fraser, P.: Three-Dimensional Model Synthesis of the Global Methane Cycle, J. Geophys. Res.-Atmos., 96, 1303313065, 1991. 
Gauci, V., Gowing, D. J. G., Hornibrook, E. R. C., Davis, J. M., and Dise, N. B.: Woody stem methane emission in mature wetland alder trees, Atmos. Environ., 44, 2157-2160, 2010.

Gibbon, A., Silman, M. R., Malhi, Y., Fisher, J. B., Meir, P., Zimmermann, M., Dargie, G. C., Farfan, W. R., and Garcia, K. C.: Ecosystem Carbon Storage Across the Grassland-Forest Transition in the High Andes of Manu National Park, Peru, Ecosystems, 13, 1097-1111, 2010.

Girardin, C. A. J., Malhi, Y., Arag ̃̃O, L. E. O. C., Mamani, M., Huaraca Huasco, W., Durand, L., Feeley, K. J., Rapp, J., SilvaEspejo, J. E., Silman, M., Salinas, N., and Whittaker, R. J.: Net primary productivity allocation and cycling of carbon along a tropical forest elevational transect in the Peruvian Andes, Glob. Change Biol., 16, 3176-3192, 2010.

Groffman, P. M., Butterbach-Bahl, K., Fulweiler, R. W., Gold, A. J., Morse, J. L., Stander, E. K., Tague, C., Tonitto, C., and Vidon, P.: Challenges to incorporating spatially and temporally explicit phenomena (hotspots and hot moments) in denitrification models, Biogeochemistry, 93, 49-77, 2009.

Hall, S. J. and Matson, P. A.: Nitrogen oxide emissions after nitrogen additions in tropical forests, Nature, 400, 152-155, 1999.

Hirsch, A. I., Michalak, A. M., Bruhwiler, L. M., Peters, W., Dlugokencky, E. J., and Tans, P. P.: Inverse modeling estimates of the global nitrous oxide surface flux from 1998-2001, Global Biogeochem. Cy., 20, 1-17, 2006.

Huang, J., Golombek, A., Prinn, R., Weiss, R., Fraser, P., Simmonds, P., Dlugokencky, E. J., Hall, B., Elkins, J., Steele, P., Langenfelds, R., Krummel, P., Dutton, G., and Porter, L.: Estimation of regional emissions of nitrous oxide from 1997 to 2005 using multinetwork measurements, a chemical transport model, and an inverse method, J. Geophys. Res.-Atmos., 113, 1-19, 2008.

Kammann, C., Grunhage, L., and Jager, H. J.: A new sampling technique to monitor concentrations of $\mathrm{CH}_{4}, \mathrm{~N}_{2} \mathrm{O}$ and $\mathrm{CO}_{2}$ in air at well-defined depths in soils with varied water potential, European J. Soil Sci., 52, 297-303, 2001.

Keller, M. and Reiners, W. A.: Soil atmosphere exchange of nitrous oxide, nitric oxide, and methane under secondary succession of pasture to forest in the Atlantic lowlands of Costa Rica, Global Biogeochem. Cy., 8, 399-409, 1994.

Keller, M., Kaplan, W. A., and Wofsy, S. C.: Emissions of $\mathrm{N}_{2} \mathrm{O}$, $\mathrm{CH}_{4}$ and $\mathrm{CO}_{2}$ from tropical forest soils, J. Geophys. Res.Atmos., 91, 1791-1802, 1986.

Keller, M., Veldkamp, E., Weltz, A., and Reiners, W.: Effect of pasture age on soil trace-gas emissions from a deforested area of Costa Rica, Nature, 365, 244-246, 1993.

Keppler, F., Hamilton, J. T. G., Brass, M., and Rockmann, T.: Methane emissions from terrestrial plants under aerobic conditions, Nature, 439, 187-191, 2006.

Kort, E. A., Patra, P. K., Ishijima, K., Daube, B. C., Jimenez, R., Elkins, J., Hurst, D., Moore, F. L., Sweeney, C., and Wofsy, S. C.: Tropospheric distribution and variability of $\mathrm{N}_{2} \mathrm{O}$ : Evidence for strong tropical emissions, Geophys. Res. Lett., 38, 1-5, 2011.

Livingston, G. and Hutchinson, G.: Chapter 2: Enclosure-based measurement of trace gas exchange: applications and sources of error, in: Biogenic Trace Gases: Measuring Emissions from Soil and Water, edited by: Matson, P., Harriss, RC, Blackwell Science Ltd, Cambridge, MA, USA, 14-51, 1995.

Malhi, Y., Silman, M., Salinas, N., Bush, M., Meir, P., and Saatchi, S.: Introduction: Elevation gradients in the tropics: laboratories for ecosystem ecology and global change research, Glob. Change Biol., 16, 3171-3175, 2010.

Martinson, G. O., Werner, F. A., Scherber, C., Conrad, R., Corre, M. D., Flessa, H., Wolf, K., Klose, M., Gradstein, S. R., and Veldkamp, E.: Methane emissions from tank bromeliads in neotropical forests, Nature Geosci., 3, 766-769, 2010.

Melack, J. M., Hess, L. L., Gastil, M., Forsberg, B. R., Hamilton, S. K., Lima, I. B. T., and Novo, E.: Regionalization of methane emissions in the Amazon Basin with microwave remote sensing, Glob. Change Biol., 10, 530-544, 2004.

Nevison, C. D., Mahowald, N. M., Weiss, R. F., and Prinn, R. G.: Interannual and seasonal variability in atmospheric $\mathrm{N}_{2} \mathrm{O}$, Global Biogeochem. Cy., 21, 1-13, 2007.

Nevison, C. D., Dlugokencky, E., Dutton, G., Elkins, J. W., Fraser, P., Hall, B., Krummel, P. B., Langenfelds, R. L., O'Doherty, S., Prinn, R. G., Steele, L. P., and Weiss, R. F.: Exploring causes of interannual variability in the seasonal cycles of tropospheric nitrous oxide, Atmos. Chem. Phys., 11, 3713-3730, doi:10.5194/acp-11-3713-2011, 2011.

Pangala, S. R., Moore, S., Hornibrook, E. R. C., and Gauci, V.: Trees are major conduits for methane egress from tropical forested wetlands, New Phytol., 197, 524-531, 2013.

Pedersen, A. R., Petersen, S. O., and Schelde, K.: A comprehensive approach to soil-atmosphere trace-gas flux estimation with static chambers, European J. Soil Sci., 61, 888-902, 2010.

Potter, C. S., Davidson, E. A., and Verchot, L. V.: Estimation of global biogeochemical controls and seasonality in soil methane consumption, Chemosphere, 32, 2219-2246, 1996.

Pumpanen, J., Kolari, P., Ilvesniemi, H., Minkkinen, K., Vesala, T., Niinisto, S., Lohila, A., Larmola, T., Morero, M., Pihlatie, M., Janssens, I., Yuste, J. C., Grunzweig, J. M., Reth, S., Subke, J. A., Savage, K., Kutsch, W., Ostreng, G., Ziegler, W., Anthoni, P., Lindroth, A., and Hari, P.: Comparison of different chamber techniques for measuring soil $\mathrm{CO}_{2}$ efflux, Agr. Forest Meteorol., 123, 159-176, 2004.

Purbopuspito, J., Veldkamp, E., Brumme, R., and Murdiyarso, D.: Trace gas fluxes and nitrogen cycling along an elevation sequence of tropical montane forests in Central Sulawesi, Indonesia, Global Biogeochem. Cy., 20, 1-11, 2006.

$\mathrm{R}$ Core Team: A language and environment for statistical computing, R Foundation for Statistical Computing, Vienna, Austria, http://www.R-project.org/, 2012.

Ridgwell, A. J., Marshall, S. J., and Gregson, K.: Consumption of atmospheric methane by soils: A process-based model, Global Biogeochem. Cy., 13, 59-70, 1999.

Silver, W., Lugo, A., and Keller, M.: Soil oxygen availability and biogeochemistry along rainfall and topographic gradients in upland wet tropical forest soils, Biogeochemistry, 44, 301-328, 1999.

Silver, W. L., Herman, D. J., and Firestone, M. K. S.: Dissimilatory Nitrate Reduction to Ammonium in Upland Tropical Forest Soils, Ecology, 82, 2410-2416, 2001.

Spahni, R., Wania, R., Neef, L., van Weele, M., Pison, I., Bousquet, P., Frankenberg, C., Foster, P. N., Joos, F., Prentice, I. C., and van Velthoven, P.: Constraining global methane emissions and uptake by ecosystems, Biogeosciences, 8, 1643-1665, doi:10.5194/bg8-1643-2011, 2011. 
Teh, Y. A., Silver, W., and Conrad, M.: Oxygen effects on methane production and oxidation in humid tropical forest soils, Glob. Change Biol., 11, 1283-1297, 2005.

Teh, Y. A., Silver, W. L., Sonnentag, O., Detto, M., Kelly, M., and Baldocchi, D. D.: Large greenhouse gas emissions from a temperate peatland pasture, Ecosystems, 14, 311-325, doi:10.1007/s10021-011-9411-4, 2011.

Templer, P. H., Lovett, G. M., Weathers, K. C., Findlay, S. E., and Dawson, T. E.: Influence of tree species on forest nitrogen retention in the Catskill Mountains, New York, USA, Ecosystems, 8, $1-16,2005$.

Terazawa, K., Ishizuka, S., Sakatac, T., Yamada, K., and Takahashi, M.: Methane emissions from stems of Fraxinus mandshurica var. japonica trees in a floodplain forest, Soil Biol. Biochem., 39, 2689-2692, 2007.

van de Weg, M. J., Meir, P., Grace, J., and Atkin, O. K.: Altitudinal variation in leaf mass per unit area, leaf tissue density and foliar nitrogen and phosphorus content along an Amazon-Andes gradient in Peru, Plant Ecol. Diversity, 2, 243-U247, 2009.

Varner, R. K., Keller, M., Robertson, J. R., Dias, J. D., Silva, H., Crill, P. M., McGroddy, M., and Silver, W. L.: Experimentally induced root mortality increased nitrous oxide emission from tropical forest soils, Geophys. Res. Lett., 30, 1-4, 2003.

Veldkamp, E., Purbopuspito, J., Corre, M. D., Brumme, R., and Murdiyarso, D.: Land use change effects on trace gas fluxes in the forest margins of Central Sulawesi, Indonesia, J. Geophys. Res.-Biogeosci., 113, 1-11, 2008.

Verchot, L. V., Davidson, E. A., Cattanio, J. H., and Ackerman, I. L.: Land-use change and biogeochemical controls of methane fluxes in soils of eastern Amazonia, Ecosystems, 3, 41-56, 2000.

von Fischer, J. and Hedin, L.: Separating methane production and consumption with a field-based isotope dilution technique, Global Biogeochem. Cy., 16, 1-13, 2002.

von Fischer, J. C. and Hedin, L. O.: Controls on soil methane fluxes: Tests of biophysical mechanisms using stable isotope tracers, Global Biogeochem. Cy., 21, GB2007, doi:10.1029/2006gb002687, 2007.

von Fischer, J. C., Rhew, R. C., Ames, G. M., Fosdick, B. K., and von Fischer, P. E.: Vegetation height and other controls of spatial variability in methane emissions from the Arctic coastal tundra at Barrow, Alaska, J. Geophys. Res.-Biogeosci., 115, 1-11, 2010.
Waddington, J. M. and Roulet, N. T.: Atmosphere-wetland carbon exchanges: Scale dependency of $\mathrm{CO}_{2}$ and $\mathrm{CH}_{4}$ exchange on the developmental topography of a peatland, Global Biogeochem. Cy., 10, 233-245, 1996.

Wania, R., Jolleys, M., and Buytaert, W.: Methane emissons from the Andean paramo - a previously neglected methane source? iLEAPS Newsletter, 7, 58-59, 2007.

Weier, K. L., Doran, J. W., Power, J. F., and Walters, D. T.: Denitrification and the denitrogen nitrous oxide ratio as affected by soil water, available carbon, and nitrate, Soil Sci. Soc. Am. J., 57, 66-72, 1993.

Werner, C., Butterbach-Bahl, K., Haas, E., Hickler, T., and Kiese, R.: A global inventory of $\mathrm{N}_{2} \mathrm{O}$ emissions from tropical rainforest soils using a detailed biogeochemical model, Global Biogeochem. Cy., 21, 1-18, 2007.

Wolf, K., Veldkamp, E., Homeier, J., and Martinson, G. O.: Nitrogen availability links forest productivity, soil nitrous oxide and nitric oxide fluxes of a tropical montane forest in southern Ecuador, Global Biogeochem. Cy., 25, 1-12, 2011.

Wolf, K., Flessa, H., and Veldkamp, E.: Atmospheric methane uptake by tropical montane forest soils and the contribution of organic layers, Biogeochemistry, 111, 469-483, 2012.

Yang, W. H., Teh, Y. A., and Silver, W. L.: A test of a field-based ${ }^{15} \mathrm{~N}$-nitrous oxide pool dilution technique to measure gross $\mathrm{N}_{2} \mathrm{O}$ production in soil, Glob. Change Biol., 17, 3577-3588, 2011.

Zimmermann, M., Meir, P., Bird, M. I., Malhi, Y., and Ccahuana, A. J. Q.: Climate dependence of heterotrophic soil respiration from a soil-translocation experiment along a $3000 \mathrm{~m}$ tropical forest altitudinal gradient, Europ. J. Soil Sci., 60, 895-906, 2009.

Zimmermann, M., Meir, P., Bird, M. I., Malhi, Y., and Ccahuana, A. J. Q.: Temporal variation and climate dependence of soil respiration and its components along a $3000 \mathrm{~m}$ altitudinal tropical forest gradient, Global Biogeochem. Cy., 24, 4011-4013, 2010a.

Zimmermann, M., Meir, P., Silman, M. R., Fedders, A., Gibbon, A., Malhi, Y., Urrego, D. H., Bush, M. B., Feeley, K. J., Garcia, K. C., Dargie, G. C., Farfan, W. R., Goetz, B. P., Johnson, W. T., Kline, K. M., Modi, A. T., Rurau, N. M. Q., Staudt, B. T., and Zamora, F.: No Differences in Soil Carbon Stocks Across the Tree Line in the Peruvian Andes, Ecosystems, 13, 62-74, $2010 \mathrm{~b}$. 